\title{
THE RISE OF ISLAMISTS IN THE MIDDLE EAST AND CHINESE INTERESTS IN THE REGION
}

\author{
By \\ Mohamed Kamal Ali Ahmed Elhomosany
}

\begin{abstract}
A thesis
submitted to the Victoria University of Wellington in fulfillment of the requirements for the degree of

Master of

International Relations

(MIR)
\end{abstract}

Victoria University of Wellington

2013 


\section{Table of Contents}

- Abstract...................................................................

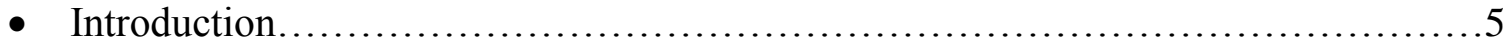

- Chapter One: The Rise of Islamists and Chinese Political and Strategic Interests.....13

- Chapter Two: The Rise of Islamists and Chinese Economic Interests..............31

- Chapter Three: The Rise of Islamists and Chinese Territorial Integrity............52

• Conclusion.......................................................... 72

• References...................................................................

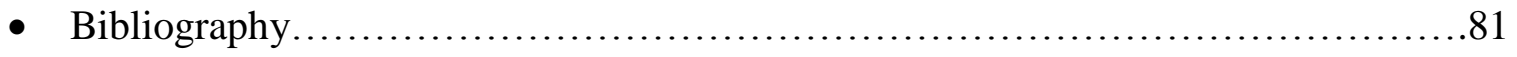




\title{
The Rise of Islamists in the Middle East
}

\section{And Chinese Interests in the Region}

\begin{abstract}
The uprising in the Middle East is representing the beginning of a new era in the history of the region. The region has not been stable during most of the $20^{\text {th }}$ century. The strategic position of the region has influenced its security. The Middle East has been part of most of the international conflicts whether directly or indirectly. During the Cold War, the Middle East has not suffered only from a division between Israel and the Arab Countries, but also between the Arab Countries themselves. The region has witnessed several times an intervention by major powers in the international system to protect their interests whether before or after the end of the Cold War. However, US supremacy after the end of the Cold War and the collapse of the Soviet Union was relatively short, as the World began a new era soon after the 9/11 attacks. The war on terrorism, the two wars in Afghanistan and Iraq, and the financial crisis were some of the factors that ended US supremacy after the end of the Cold War and started the US decline. At the same time, the international system has started to shift from uni-polarity to multi-polarity with the rise of new regional powers most prominent among them is China. The rise of China will affect the international system and have its impact on the Middle East. Besides the changes of the international system, the Middle East has witnessed uprisings late 2010
\end{abstract}


and beginning of 2011 that led to the removal of the three regimes in Tunisia, Egypt, and Libya. Although the new regimes have not been fully established, the rise of Islamists is one of the main consequences of such changes. Whether such changes in the Middle East can affect the interests of China in the region positively or negatively is the subject of this research. China's interests in the region can be identified in three main categories: political and strategic interests; economic interests; and the effect of the developments in the region on Chinese territorial integrity in Xinjiang. To what extent the new environment will give the chance to China to extend its influence in the region beyond the traditional limits imposed on its interests?, and whether the new regimes in the region under the Islamists rule will seek a stronger relationship with China, to balance the influence of the US in the region, is the focus of this research. The research concludes that the rise of Islamists will not positively influence the political/strategic and economic interests of China in the Middle East at least in the short run and it will not negatively influence the sovereignty of China over Xinjiang. 


\section{Introduction:}

China has three core interests. The first one is domestic security. Traditionally, China used to face the problem of development disparity between the coastal areas and the core of China. Whenever China develops trade with the outside world, the coastal regions become more prosperous than the core region. China sought to overcome the gap between both sides through mass employment. With this goal in mind, China had to raise private savings to develop its industry leaving little capital for purchasing the output. Hence, China had to export its products to the foreign markets. The second strategic core interest derives from the first. China has to export its products because its industrial base produces beyond the domestic demand. This also means that China has to ensure its access to foreign markets and secure foreign demand. This goal can be achieved through securing access to sea lanes and investing in consuming markets, while at the same time importing raw materials from overseas. The third strategic core interest is controlling the buffer states like Inner Mongolia, Xinjiang, and Tibet. The control of buffer states provides the Chinese Han in the eastern part of the country with security, due to the inherent natural barriers like mountains and deserts that offer security against outside powers. China is facing challenges in the three above core interests. The economic down turn in Europe and the United States decreased the demand on goods and the exports of China, besides the low domestic demand in China, which is not strong enough to offset the decreased exports. In fact, the Chinese model of mass employment and market share miss-allocates resources and does not allow the mechanism of supply and demand to work for determining prices which results in inflation. Hence, China moved from low 
value added products to high value added ones to increase its profits, but this challenge needs more highly educated people and more competition with developed industrial countries. On the other hand, China's access to sea lanes, which is vital for its exports and imports of energy resources, is not guaranteed. The geographic location of China is challenging in terms of access to sea lanes, because the East China Sea and the South China Sea can be blocked easily by any major power like the US. The East China Sea can be blocked through the limited distance between Japan and Taiwan, while the South China Sea can be blocked through the limited distance between Taiwan and Philippines and at the Strait of Malacca. To overcome the above challenge, China has to acquire the military naval capabilities that allow China guaranteed access to sea lanes. But the People's Liberation Army (PLA) has been an internal armed force focused on preserving internal security, hence China decided since the 1970's to develop its naval strategic doctrine to acquire naval capabilities that can defend its interests in the regional seas especially in the South China Sea. The only power that can block China's access to sea lanes is the US, which is an extreme option in case of any conflict. This means that China has to build its own naval capabilities including an aircraft carrier and a battle group. Recently, China started to sail its first aircraft carrier, but still it is a long way before the Chinese personnel can master the command of the aircraft carrier and its battle group. In fact, it may take generations to reach to the present capabilities of the US. Accordingly, it was easier for China to look for acquiring asymmetric power capabilities that may balance the US capabilities like developing land based missiles and submarines. The land based missile capabilities can drive the US aircraft carriers and warships out of the regional seas, but still the missiles need satellite capabilities for detection and control. On 
the other hand, the US has anti-satellite capabilities, which can render the missiles capabilities useless. The other option available to China is trying to avoid depending on South China Sea and East China Sea through direct access to the Indian Ocean. This goal can be achieved through having port access in Indian Ocean countries like Myanmar, Pakistan, Sri Lanka, and Bangladesh. China is funding the building of ports in these countries and the needed access through railways and pipelines. Although this option would decrease China's dependence on the Malacca strait only relatively, but still it puts other challenges on China because of the unstable situation in these countries, which makes it difficult for China to build its own strategy upon regimes that can be changed in any moment, besides the vulnerability of the railways and pipelines to any attack. But still China is working on the different options and balancing the relations with the US at the same time (Buszynski December 2003; Friedman 2012).

Within the framework of the above strategy, we will look into China's Middle East policy and how its interests in the region fit into its strategic core interests. China has neither historic ties like the Western Countries nor long standing strategic interests within the Middle East. Since the beginning of reform in China, the Chinese policy towards the region was directed more by pragmatic policy that sought to promote development at home by obtaining profits - through trade and arms sales - and securing energy resources (Rubin March 1999: 46 - 54).

Traditionally, there were three main interests for China in the Middle East: ideology and self-image, economic interests, and the Middle East direct or indirect linkages with interests closer to home. 


\section{Ideology and Self-image:}

Since the communist revolution and through the 1970s, China has considered itself as revolutionary vanguard that is spreading Marxist-Leninist ideology and accordingly it helped some political groups in the Middle East like the Palestinian Liberation Organization (PLO) and the Popular Front for the Liberation of the Occupied Arab Gulf (later the Popular Front for the Liberation of Oman). However, the ideological fever of China changed or faded after the end of the Cold War and the internal changes in China (Rubin March 1999: 46 - 47). We can say that the ideological fever was replaced by pragmatic political and strategic relations with the region that sought to support development at home.

\section{Economic Interests:}

While China was looking for modernization at home, it sought to support its modernization and development process through trade and exports to the Middle East and at the same time securing energy resources from the region. But China had entered the region late compared to other powers. To face this challenge, China decided to trade with marginal or rogue states in the region where no one would trade with them and sell such states goods no one would sell them, but at the same time without sacrificing the relations with the US. China's response to arms sales criticism is that all weapons sales to the Middle East should be limited and until then it will continue arms sales like other countries (Rubin March 1999: 47 - 50). 


\section{Linkages with other strategic interests closer to home:}

There have been always linkages between China's interests and relations with the Middle East and between other strategic interests on the top of China's agenda. China had to make a compromise with the US concerning its sales of arms and nuclear proliferation in the region on many cases, as China gave more priority to its vital relations and interests with the US. One of the clear instances in this regard was in January 1998, when Bill Clinton submitted to the Congress a nuclear cooperation pact with China and the White House Spokesman said at that time that the President was satisfied that China has met the conditions of nuclear non-proliferation (Rubin March 1999: 50 - 52).

However, China's foreign policy in the region has developed from a development driven diplomacy since the beginning of reform into a diplomacy that balance different political, strategic, economic, and legal Chinese interests. For example, recently in the case of the uprising in Syria, China had to balance between its political, strategic, energy interests in Syria, and the principle of territorial integrity on one hand, and its economic and political interests with the Gulf Countries, the US on the other hand. China's policy is taking into consideration more broad interests nowadays than earlier periods. China as a rising power has concerns about the developments in the region and its implications for its global policy and interests.

Taking into consideration the changes in the Middle East, the research will consider the effect of one main variable, which is the rise of Islamists in the region, on the three variables: political and strategic interests; economic interests; and the 
territorial integrity of China. The effect of the rise of Islamists on the three variables will be discussed separately in each chapter.

To what extent the three interests of China in the region - namely political and strategic interests, economic interests, and the territorial integrity of China - will be affected by the rise of Islamists in the Middle East is the focus of this research. Accordingly, the General Question of the research will be: What is the effect of the rise of Islamists in the Middle East on the Chinese interests in the region? The answer for this question is: The uprising in the Middle East will not positively affect China's interests in the region at least in the short run.

Other questions to be raised in the framework of the general question are as follows:

1. What is the effect of the rise of Islamists in the Middle East on the Chinese political and strategic interests in the region?

2. What is the effect of the rise of Islamists in the Middle East on the Chinese economic interests in the region?

3. What is the effect of the rise of Islamists in the Middle East on the Chinese territorial integrity?

The first chapter will discuss the political and strategic interests of China in the region, and the traditional relationship of China with Iran, Israel, the Gulf Countries, and the possibility of extending such strong relations to the new regimes under the leadership of Islamists or their influence through coalition governments or their representation in the national parliaments. 
The second chapter will deal with the economic interests of China in the region with focus on energy security and trade with the region. The increasing energy needs of China put pressure on Chinese officials to achieve energy security. Chapter two will consider the concept of energy security and the debate inside China about achieving energy security. In the same chapter, the research will discuss the development of China's relations with the region in terms of "oil diplomacy", the present situation in terms of oil imports from the region, and the successes and challenges facing China in this regard. Chapter two will also discuss the trade relations between China and the region especially through the China-Arab States Cooperation Forum, then the challenges facing China after the uprising in the region with special focus on the case of Libya.

The third chapter will deal with the influence of the situation in the Middle East on Chinese territorial integrity especially the case of Xinjiang taking into consideration the rise of Islamists in the region. The chapter will begin with brief background of the history of the problem of secession in the Xinjiang and China's position towards Xinjiang, then the position of the Arab countries in this regard, before concluding with discussing the influence of the rise of Islamists in the Middle East on the issue of Xinjiang.

The methodology of the research will depend on the Neo-realism as a framework of analysis. The Neo-realist theory offers the most convenient analytical tools for the topic of the research. Structural Realism's themes, about the competition for power and security, and the anarchy on the level of the international system, can explain many features of the Chinese strategic interests. China's competition with the US to acquire 
access to raw materials including energy resources and achieving energy security will be explained within the framework of the Neo-realist themes.

The debate also about balancing or bandwagoning between the US and China is reflected on issues like securing access to sea lanes by China for trade and importing raw materials or bandwagoning on the US for offering such security. The conflict between morality and Chinese foreign policy in the Middle East will be raised in the research. The conflict will appear in different aspects related to the Chinese foreign policy in the Middle East like importing energy resources from countries like Sudan, which violates human rights in the eyes of the West or selling arms to regimes considered to be rogue by the West like Iran. In fact, the most recent issue of morality in China's policy towards the region is the case of Syria.

China has supported the regime in Syria after the uprising. China declared its respect for the choice of the Syrian people and called for resolve of the conflict by peaceful means through negotiations; non-interference by the international community in Syria; and respecting the territorial integrity of Syria. While China condemned killing of civilians by the regime, it gave more priority for observing the territorial integrity of Syria, non-interference by the West, and avoid creating precedence more than respecting human rights and stopping the killing of civilians.

It is noteworthy that the research will depend on the definition of the Middle East as a region that includes the Arab countries in West Asia and North Africa, Turkey, Iran and Israel. 


\section{Chapter One:}

\section{The Rise of Islamists and Chinese Political and Strategic Interests}

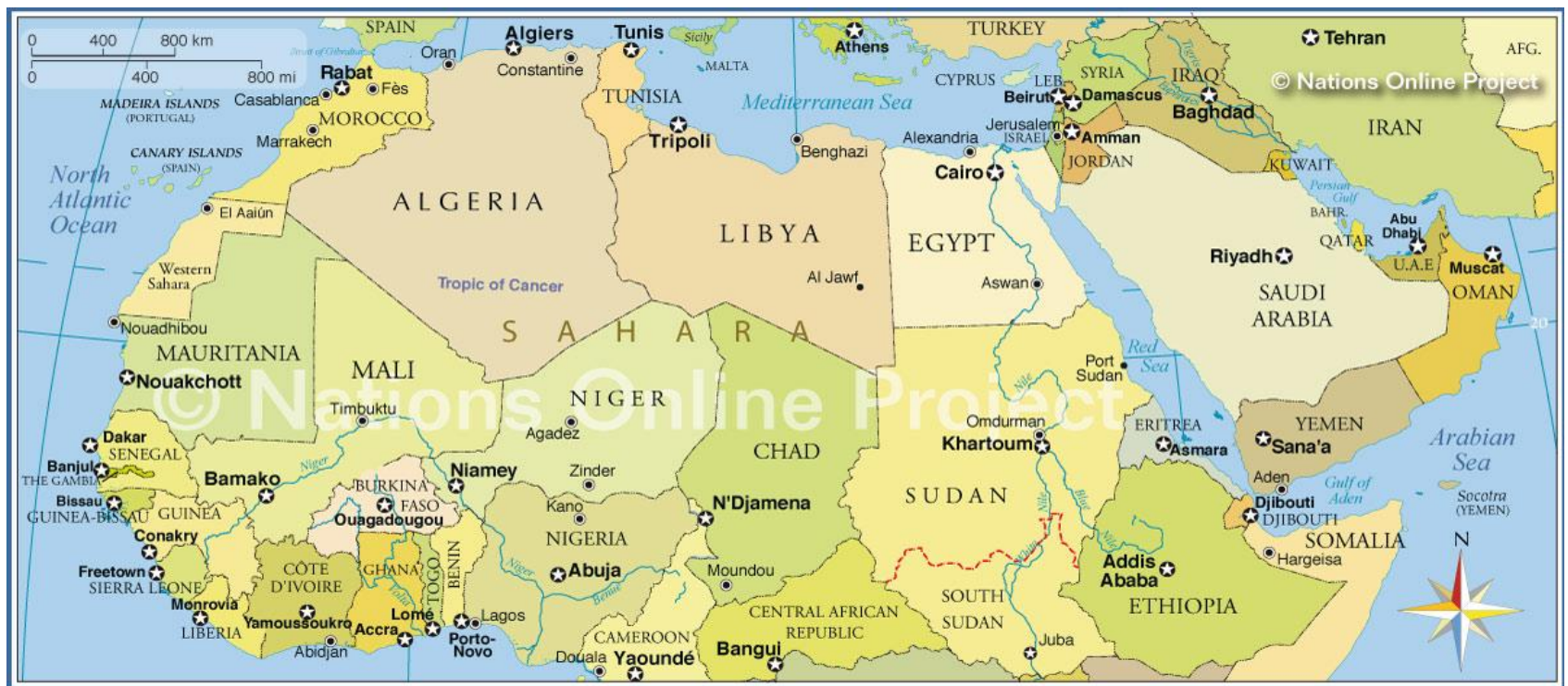

Source: Nations Online Project. (The Southern border of Egypt must run in a straight line $\left(22^{\circ} \mathrm{N}\right)$, until it reaches the Red Sea to reflect the official demarcation of borders and authoritative borderline between Egypt and Sudan according to the former Egyptian Minister of Foreign Affairs Ahmed Aboul-Gheit: http://www.ahram.org.eg/archive/Arab-world/News/27927.aspx).

After the end of the Cold War Chinese officials noticed that there are positive and negative aspects resulted from the change in the international arena from the perspective of China's interests. The negative aspects include the failure of socialism in the ex-Soviet Union and East Europe; the strategic triangle that characterized Chinese foreign policy with the ex-Soviet Union and the US disappeared; the era after the end of the Cold War witnessed the rise of territorial, ethnic, and religious conflicts; and the increase in global competition based on economic and science dimensions. On the other hand, the positive aspects from the perspective of China in the international arena included the Asia-Pacific region, which enjoyed relative tranquility, political stability, and economic boom; the rivalry on the international level became between economic powers and groupings 
instead of military blocks; the economic problems in the US increased; and the transition difficulties faced by Russia, ex-Soviet republics, and East European countries after the collapse of the communist regimes, which confirmed to the Chinese people the viability of China's system (Chen March 1993: 238 - 240).

Accordingly, China concluded that the threats after the Cold War come from economic and scientific challenges like the economic and scientific gap with Western industrial countries; the gap with Asian New Industrializing Economies (NIEs); the gap with ASEAN countries; and the probability that East European countries may complete transformation and take off. The above background might have given China the incentive to adopt new approaches in its foreign policy based on good relations with its neighbors; improving relations with all countries; and play an active role in UN for peace, stability, and prosperity (Chen March 1993: 240 - 245). However, other researchers like Deborah Welch Larson and Alexei Shevchenko have considered that the new changes in China's foreign policy as a part of "status seekers", as China aimed to gain membership in the group of Western civilized countries, which are considered a model to the developing countries (Larson, Deborah Welch and Shevchenko, Alexei Spring 2010).

China had no choice but to bridge or at least narrow the gap with the developed countries and the new emerging economies in East Asia. Besides the nature of the Chinese economy necessitated that China continues to access foreign markets and increase its exports. China's political interests in the Middle East have changed after the beginning of the reform process and also after the end of the Cold War. The role of ideology in China's foreign policy decreased as the main interest became to preserve the international conditions necessary for the continuation of economic growth internally and 
this was confirmed after the end of the Cold War and the role of ideology in international affairs decreased with the rise in economic competition between different blocks. The new foreign policy of China in the region is influenced beyond oil by the three notions of preservation, prosperity, and power, according to Melinda Baker. She clarified that due to its historical experience, since Mao announced the five principles of coexistence in 1954, the maintenance of territorially unified China that can face any external negative influences became a primarily goal of Chinese foreign policy. The notion of preservation was reflected in one China policy with political preservation included external and internal dimensions. The external dimension included preservation of economic growth, stability, and order, while the internal dimension included preservation of sovereignty and non-interference by external powers. The notion of preservation was reflected also in the socio-cultural dimension and sought to avoid any interference by the West that can lead to regime change under the pretext of human rights and democracy (Baker 2010: 5 9).

The second notion which is prosperity comes after preservation and under this notion China was expressing foreign policy based on the concepts of non-interference; pragmatism; fairness and equality in opportunities; and multilateralism. The third notion is power, which is needed to protect all of the above concepts of economic growth, stability, sovereignty, and non-interference. The power concept includes material capabilities; influence and coercive power; and ideational power (Baker 2010: 11 - 12).

Melinda Baker noticed that in the context of the above analysis the Sino-Iranian relationship provides advantages to both sides. For China, Iran has huge reserves in oil, which is considered to be the third largest proven oil reserves ( $520 \mathrm{bbl} / \mathrm{d})$, and the second 
largest natural gas reserves (50 tcm, trillion cubic meters). Iran's energy infrastructure and capabilities are underdeveloped, which is a good investment opportunity and a good opportunity to secure future needs especially that Iran needs capital and technology to develop its energy sector. At the same time, China is looking for reliable suppliers not under the US allegiance. For Iran, China's energy needs will not be alleviated any time soon on the contrary it will increase. Also China's non-interference policy is more convenient to Iran compared to the policies of Western countries, which interfere in the internal affairs of the developing countries on the grounds of democracy and human rights. In addition, Iran is aware of the influence that China has in the UN and the role it can play as a Security Council permanent member (Baker 2010: 19-20).

In fact, the Sino-Iranian relations or contacts date back to at least the second century when the Han Dynasty initiated the Silk Road with the Parthian Empire. However, the Shah relations with communist China were negative due to the orientations of both regimes to the extent that China supported the Iranian opposition and the Shah established diplomatic relations with Taiwan in 1956. But the relations between them witnessed a change with the US - Soviet Détente in the 1960s, which facilitated the rapprochement between China and Iran, and in 1971 Iran supported Communist China entry into the UN and both countries resumed diplomatic relations (Gentry November 2005: $111-113)$.

The relations between China and Iran entered a new era after the Islamic Revolution in 1979 as both countries were not on good terms with the West and pragmatism in their relations continued as was reflected by ignoring the persecution of communists in Iran and Muslims in China. Iran and China signed a nuclear cooperation 
agreement in 1992, although nuclear cooperation between them started secretly in the 1980s. China also helped Iran to rebuild its depleted military capabilities after the IraqIran war in the early 1990s. In 1993, both countries established a joint commission on economic, trade, scientific, and technical cooperation (Gentry November 2005: 113 114), and they signed a joint communiqué for long term friendship and cooperation in 2000 (Baker 2010: 21 -22).

In the field of energy two agreements were signed in the 2004. The first was in March 2004 in which the state-owned Zhuhai Zhenrong Corporation to import 110 million tons LNG over 25 years a deal worth approximately US\$20 billion. The second was in October 2004 in which the state-owned Sinopec to import 250 million tons LNG over 25 years a deal worth US $\$ 100$ billion, and at the same time develop and exploit Yadvaran oil field from which China receive 150,000 barrels of oil a day for 25 years. In April 2005, Sino-Iranian Memorandum of Understanding was signed on the expansion of bilateral trade and cooperation (Gentry November 2005: 114 -118).

In the field of military cooperation, China has supplied Iran with an estimated US\$3.8 billion of conventional arms between 1982 and 2004. China was the most significant partner to Iran until the late 1990s and even after that it continued to offer Iran technical assistance and dual use technology for its nuclear programs. However, China's support to Iran was tied to US-Taiwan relations. In all the cases that witnessed American arms sales to Taiwan, China responded by increasing its military cooperation or sales in the Middle East, for example the Regan Administration arms sales to Taiwan in 1982 or the US sales of 150 F-16 aircrafts to Taiwan in 1992 or even after the visit of Taiwan President Lee Teng-hui to the US in 1995 (Baker 2010: 26 - 28). 
However, China's military cooperation with the region was not confined to Iran only as China was seeking to build relations with countries who are looking for weapons and military technology that they can not get from the West and also as a source of economic profit for China to cover at least part of the cost of its energy imports. Accordingly, China had interest in keeping WMD and missiles cooperation with Iran, Saudi Arabia, and Pakistan as they represent access points for China in the Greater Middle East and even Israel as a source of advanced military technology. For example, Saudi Arabia purchased CSS-2 intermediate range ballistic missiles from China and the deal was publicly revealed in March 1988 after the deal was accomplished and the missiles were transferred already. China sold also to Iran HY-2 silkworm cruise missiles and under pressure from the US, China pledged to the US in March 1988 to stop missiles sales but in January 1996 Iran tested C-802 anti-ship cruise missile and under pressure again from the US, China pledged to stop sales to Iran in September 1997 (Russell September 2005: 109 - 116).

Although China has built strong relations with Iran and other countries in the region over the years, it also established good relations with Israel at the same time since the beginning of the 1990s. Israel is a source of technology for China especially the military one, but to have a good assessment of the relationship between both countries, we should review in short the development of relations between Israel and China and the effect or influence it may have on China's policy towards the Middle East.

Israel has noticed the ongoing change in the international system and the rise of new powers like China, India, and Brazil. Israel decided to strengthen its relations with the rising powers during an era in which the power of the US, its traditional ally, is 
declining. Israel could not disregard any more the voting power of the Third World Countries at the different organs of the UN and the subsequent condemnation of Israeli policies against the Palestinians in the occupied territories.

According to Aron Shai from Israel perspective China's economic growth and rise will continue in spite of speculations by some analysts that China will face a crisis due to some economic hardships internally. While China is rising, the US is relatively declining and in such cases the interests of the client states like Israel may be at risk. Hence, Israel should consider new ways to strengthen its relationship with China (Shai September 2009: 8 - 10).

China under the Guomindang regime had established relations with the Zionist Movement and later on abstained from the 1947 vote in the UN General Assembly on the partition of Palestine into two states one of them is Israel and the other is Palestine. After the creation of Israel in 1948 the relations between China and the new state of Israel continued. After few months from the creation of Israel, Nationalist China recognized Israel. However, after the victory of communist China, Israel recognized PRC and the relations with Taiwan were conducted on unofficial, non-governmental, and commercial levels to avoid any problems with communist China and as Taiwan also did not want to upset anti-PRC Arab countries. However, Israel's recognition of China in January 1950 was not reciprocated by China. With the establishment of full diplomatic relations between China and Israel in January $24^{\text {th }}, 1992$, the relations with Taiwan became freer and direct, and both exchanged cultural and economic liaison bureaus. Israel had its own reasons when it recognized the PRC as Israel was a moderate socialist state and followed an evenhanded diplomacy of non-alignment at that time, besides Israel wanted to give a 
positive gesture towards PRC to help in the Immigration of Jews in China to Israel. After the Korean War broke out in 1950, Israel supported the UN forces by medical aid and food for civilian relief, which had led to indirect confrontation with China. But Israel continued its policy of evenhandedness towards China in other spheres especially when it supported China in assuming its UN seat on September $19^{\text {th }}, 1950$. The deterioration of relations between both countries occurred after the Afro-Asian Conference in Bandung in 1955, which boycotted Israel and Taiwan and also after the Suez War in 1956. Also at a certain point, Israel had to change its evenhandedness policy towards China to avoid damaging Israeli-American relations and it adopted the Western stance on China (Shai September 2009: 18 -22).

Even on the level of Israel Communist Party (ICP), there were differences with CCP in China. After ICP was divided in 1965 into two rival parties, the differences continued as both parties criticized China on a number of issues like the Cultural Revolution and relations were only restored in the late 1980s with the internal reform in China. However, a new era in the relations between Israel and China started in 1979 during the war between China and Vietnam as China faced a crisis and looked for military and technological assistance from a country familiar with Soviet weapons. Israel stepped in as it had experience with the Arab states' Soviet weapons and supplied China with T-59 tanks. During the period from 1989 to 1991, the relations between both countries developed as a Chinese tourism office was opened in Tel Aviv and an Israeli academic mission opened in Beijing. The changes that occurred in the region since the visit of Sadat to Israel in 1977; the Peace Treaty in 1979; the end of the Cold War; the changes inside China and China's desire to play a role in the Middle East peace process 
had led to the establishment of full diplomatic relations between Israel and China in 1992. The cooperation and trade between the two countries has focused on science, technology, and hi-tech products. On the level of trade, Israel's Trade Mission to China website mentioned that trade volume between Israel and China has reached US\$6.8 billion in 2010. The Chinese exports to Israel have reached US $\$ 4.7$ billion, while imports from Israel have reached US\$2.1 billion (http://itrade.gov.il/china-en/bilateral-tradereview/). However, since 1992 the US has raised concerns over transfer of military technology to China whether Israeli technology or US derivative technology. The case of the Phalcon deal is the most prominent example for the US concerns about the military cooperation between China and Israel. In the mid-1990s, Israel agreed to sell to China the Phalcon aircrafts, which is a sophisticated airborne radar system at the price of US $\$ 250$ million each. Such capabilities would have provided China with large capabilities in control and command taking into consideration the lack of developed naval capabilities for China in large areas like the South China Sea compared to the US. However, after years of consideration between Israel, China, and Russia, who was supposed to offer the aircrafts into which the radar system would be installed, the deal was cancelled in July 2000 and Israel had to pay to China US\$319 million for the deposit amount that was already paid and for compensation (Shai September 2009: 22 -28).

Another incident occurred when Israel sold the Hary drones to China in 1994 and contracted to repair and service them in Israel in 2004 and 2005, but the US objected about the deal because it thought Israel would upgrade them. On the other hand, China continued to cooperate in the military field with other countries in the region like Iran in spite of the improvement in relations with Israel. Such military cooperation raised 
concerns in Israel after the second Lebanon War, when a missile fired by Hizbuallah damaged an Israeli warship "Hanit" and killing four sailors. Israel assumed that the fired missile which is C-802 Silkworm land to sea anti-ship was sold to Iran a decade earlier. However, the technological cooperation between the two countries continued as they signed an agreement at the time of Phalcon contract cancellation and almost equal in value for Israeli-made HK1 and 2 satellites to broadcast the Olympic Games in Beijing (Shai September 2009: 28 -30).

But there are others who defended the military cooperation between China and Israel or between China and the rest of the Middle East like Yitzhak Shichor. He mentioned that the arms transfer from China to the Middle East has started in the early 1980s, but the impact of such sales on the balance in the region is doubtful in terms of quantity and quality. The percentage of Chinese arms sales is limited compared to other suppliers in terms of quantity. He gave an example of an incident in 1992 in which China cancelled two 20MW research reactors to Iran under US pressure and in 1995 two 300MW power reactors to Iran were also cancelled.

Yitzhak Shichor added that Israel sought from the military cooperation with China to moderate China's pro-Arab policy and to achieve economic profit after Israel had lost its traditional customers in Iran and South Africa, while China sought from such a relationship to acquire military technology not only final weapons. After the collapse of the Soviet Union, China found a new source for weapons apart from Israel because Russia needed money so it opened its military warehouses to those who needed arms, which was convenient for China and the Middle East countries because Soviet arms were easier to integrate with local military equipments and China happened to have money to 
pay. According to Yitzhak Shichor earlier information by US Agencies about transfer of arms to China were not accurate. The Phalcon deal was signed in July 1996. The US kept quiet in the beginning because the technologies used to install the system to a converted Russian IL-76 (A-50 airframe) transporter were not American ones, but later on the US opposed the deal because it would have disrupted the balance of power in East Asia, undermine US interests, and raise risks to US troops in East Asia (Shichor 2000: 69 76).

Besides the cooperation between China and both Iran and Israel referred to above, China expressed its wish to play an active role in the peace process. On April $26^{\text {th }}, 2009$, while in Damascus the Foreign Minister of China, Yang Jiechi, issued a 5-point proposal to advance the peace process. First, the parties should continue the peace process on the basis of relevant international resolutions and initiatives. Second, the parties should take positive confidence building measures. Third, the two state solution. Fourth, the international community should continue its efforts to solve the Palestinian issue including the internal economic and political challenges. Fifth, peace negotiations on various tracks should be coordinated to advance a comprehensive peace in the Middle East. But still the US and Quartet play the major role in the peace process. However, China is sensitive towards the situation in the occupied territories, because if it persists on strongly support self-determination for Palestinians then China may face the same situation in Xinjiang or Tibet (Shai September 2009: 32 - 34). 


\section{The Uprising in the Middle East and Future Relations with China:}

As it was mentioned above, traditionally China managed to build strong relations with different countries in the Middle East especially those countries which used to oppose the US and Western policies in the region. The relations between China and Iran is a good example of how the Chinese as late comers to the Middle East decided to deal and trade with countries, which no one would trade or deal with them. But also China had built good relations with other countries like Israel. The relations with Israel serve the purpose of the transfer of needed technology to China, which would allow China to continue its economic growth and to increase its exports and would offer China the needed military technology to modernize its army.

On the other hand, China's relations with other countries in the region like Egypt were not very strong like the relations with Iran. Although, Egypt was the first country in the Middle East and Africa to recognize communist China, but the relations between both countries were not very strong, especially since Egypt shifted its policy from the exSoviet Union to the US in the 1970s. Egypt has been considered by China as a proWestern country.

However, the situation changed after the uprising in Egypt. The Islamists rise in the subsequent elections has raised the prospects for a change of the foreign policy of Egypt. To assess the situation in Egypt and the prospects for change, we should consider the influence of the Military Institution and whether they would accept such a change and whether the Islamists would be capable to enforce their policy over the Military institution in this regard. 
Although, in Egypt the Islamists' policy towards the West and Israel during the past period was mixed as they criticized among others the US for offering funding to the Egyptian NGOs against the Egyptian law, but on the other hand they have declared several times that they would respect any agreements that were signed during the previous regime including the Peace Treaty with Israel.

The Military Institution represented by the Supreme Council of Armed Forces (SCAF), which is assuming the powers of the President until the election of a new President, has built strong relations over the years with the US and managed to keep stable relations with Israel since the signing of the Peace Treaty in 1979.

Shana Marshall talked about the Egyptian Army's revolution in terms of its new Military Industrial Complex. She explained that the Egyptian Military has been coproducing weapons with different Western and non-Western arms manufacturers, but it was obvious that most of the production lines and maintenance facilities are remnants of contracts concluded in the mid-1980s and early 1990s, besides owing primarily to poor quality, the Egyptian Army had limited market for exportation of its defense products. This situation has led to directing more production to the Egyptian Army more than its actual needs. However, the Military planners in Egypt understand that the best way to modernize their military industrial base is through cooperating with second and third class foreign military manufacturers on small scale projects that may be willing to transfer technology to Egypt in exchange for lucrative contracts. This approach was reflected in the establishment of the new three billion Egyptian pound "Mubarak Complex for the Defense Industry". The new industrial complex included the relocation of several military factories to the new complex. The new complex will host 28 factories 
by the end of 2012 with plans to add 34 other factories. The new complex will host also a two hundred million Egyptian pound laboratory and technical education complex, which would help to transfer defense technologies later on, according to former Minister of Military Production Sayed Meshaal, who said also that the Egyptian Army is constructing another complex "Mubarak Complex II". The Egyptian Army focuses on cooperating with smaller-tier suppliers, the same way United Arab Emirates and Jordan have done before, because first the related projects are more likely to result in sustainable production activities as they do not involve the transfer of sensitive technologies, second the subsidiary firms and smaller independent manufacturers are more willing to accept co-production with other countries like Egypt to secure sales in a market characterized by competition from big arms manufacturers. She added that "examples include a waterjetpowered fire-fighting vessel (with $4 \times 4$ vehicle deployment ramp) built in 2004 by the Helwan Company of Machining and Equipment (factory 999) based on design technology and materials provided by Teknicraft Design (of New Zealand) and MAPSO the local Egyptian agent of Hamiltonjet (also of New Zealand)". Another example is what Wikileaks cables revealed that the South Korean firm Hanwha (subcontractor of Samsung) had requested US approval for transfer of US-origin technologies to the Egyptian Company Abu Zaabal Company for Specialty Chemicals in 2008, such technologies would be used for testing propellants for the manufacture of $155 \mathrm{~mm}$ ammunitions (howitzers). Cooperation with foreign manufacturers has extended also to Chinese companies through the Kuwaiti Kharafi Group, which has several joint ventures with the Egyptian Military. The US embassy cables released by Wikileaks revealed that the Egyptian Division for Kharafi purchased a Chinese firm called Sitex, which is 
manufacturing a radio technology used in the fire-fighting vessel design provided by Teknicraft of New Zealand referred to above. The cables mentioned also that the goal of the purchase was technology transfer (Marshall 10/02/2012).

Another example for cooperation with the Chinese companies was "In 2000, Egypt began to work on assembling Chinese-designed K-8 jet fighters, a collaboration that included a second phase of jet assembly in 2005 and the establishment of an aviation research facility in Cairo. (Ironically, the K-8s assembled in Egypt are outfitted with engines from Honeywell -- the same firm that supplies parts for the U.S.-designed M1A1 tank)" (Marshall 29/02/2012). A third example was "At a 2010 ceremony, the Arab Organization for Industrialization (AOI) chairman announced that a new cooperative agreement between the two countries would soon yield joint production in new combat items (perhaps the local assembly of the JF-17, a jet of joint Chinese-Pakistani design)" (Marshall 29/02/2012). The fourth example of cooperation was in 2011, when the Aviation Industry Corporation of China signed an agreement with the Arab Organization for Industrialization (AOI) to collaborate on a range of aviation applications including the establishment of a research and development facility in Egypt (Marshall 10/02/2012).

The above development or revolution refers to the plans of the Egyptian Army to modernize its capabilities, but does it mean that the Egyptian Army is going to shift its policy away from the US?, and May it support any policy that negatively affects the interests of the US?, like increasing military cooperation with China or allowing the new regime to advocate a new policy away from the West, would it be possible for the new regime to neglect the strong and huge interests between the Military and the transnational capital? (Marshall and Stacher spring 2012). In fact, the answer depends on who will be 
the next president and whether he will be from the Islamists or other political groups. But in general the next president will have to take into consideration the different interests with the US and strong military cooperation between both countries.

Apart from the above cooperation with the US in the co-production of M1A1 tanks, Egypt receives US $\$ 1.3$ billion Military grant from the US, which is divided into new weapons acquisitions; upgrading to existing equipment; and follow-on support and maintenance contracts. Egypt is also receiving Excess Defense Articles (EDA) worth hundreds of millions of dollars from the Pentagon. In terms of training, Egypt is participating in the "International Military Education and Training (IMET)" program and in 2009 Egypt received US\$1.316 million. Concerning the economic assistance, the amount decreased from around US\$800 million to US\$250 million now. Finally, Egypt is receiving funds for counter terrorism, border control, and technical cooperation. In 2008, that amount was US\$3.545 million, but an exceptional funding was in 2009 as the US paid US\$52 million, in that year there was an additional funding of US\$50 million directed to strengthening border security at Rafah between Egypt and Gaza Strip for combating smuggling of weapons (Sharp 2010: 4-7).

Even during the last crisis in the relations concerning the American NGOs role in Egypt and the illegal funding accusations against them, the US did not cut the military assistance to Egypt and SCAF intervened in the legal process to release the American members of the NGOs. According to Shana Marshall, the US won't cut the military aid to Egypt because the military aid benefits a group of elites in both countries. For the US, it offers a stable and large source of demand on US weapons exports. For Egypt, coproduction, with US arms manufacturers, helps in subsidizing the army's commercial 
economic ventures. Shana Marshall has given an example "for instance, the General Dynamics manufacturing facility in Lima, Ohio where the M1A1 Abrams tank is built will not have more work orders from the U.S. Army until 2017 when the current M1 tank fleet is up for refurbishing. Egypt's latest $\$ 1.3$ billion order of 125 M1A1s (Cairo's 11th order since the late 1980s) will keep those production lines open until 2014 building knock down kits that are then shipped and assembled in Egypt" (Marshall 29/02/2012). Although "The increasing indigence of production in Egypt may imply the loss of U.S. jobs -- but it is shareholder value (not work-hours for blue collar Americans) that dictates General Dynamics's corporate planning" (Marshall 29/02/2012). Also outsourcing makes Egypt heavily invested in production of M1A1 tanks and keep directing its aid dollars to procure more tank kits and at the same time the US weapons manufacturers prefer outsourcing components because it increases the per-unit price of equipment and accordingly their revenues (Marshall 29/02/2012).

The strong relations and shared interests between Egyptian Military and the US arms manufacturers might put limit on the ability of China to develop its relations with Egypt in the field of military cooperation at least during the coming short period in spite of the present level of cooperation between Egypt and China, but the situation may change if the Islamists mainly the Muslim Brotherhood or another political group that perceives the policies of the US in the region negatively assumed power, as the new regime may look forward to develop relations with China as an alternative rising power. If this happened, then the uprising in the region would provide an opportunity for China to develop its relations with a country like Egypt, which used to be perceived by the Chinese government as pro-Western for a long time. China certainly would use such an 
opportunity to avoid or maybe compensate for losing a leader like Muammar Gaddafi in Libya. The recent visit by the President of Egypt, Dr. Mohamed Morsi, to Beijing in August 2012, can be considered at least a step in the direction of a more balanced Egyptian foreign policy between China and the US. The visit witnessed the signature of about 8 economic agreements worth of US\$4.8 billion (Xinhua 30/08/2012).

According to some analysts China and Russia had felt betrayed by the US after it used the UN resolution concerning Libya to carry out a military attack against the regime. This explains to a great extent the third veto raised at the UN Security Council recently by China and Russia against the draft resolution concerning the situation in Syria. The official statements by the Chinese officials reflected China's concerns about the Western attempts to change the regime in Syria by putting increased pressure on the regime. Many Chinese officials declared that China respects the wishes of the people in Syria, and calls for peaceful settlement of the conflict by negotiations between the regime and the opposition, while at the same time the territorial integrity of Syria should be respected. China has a clear concern that the situation in the region may become an incident that can be repeated elsewhere or even in China itself especially the intervention by the West for humanitarian reasons. China and Russia are trying to protect the Syrian regime, which has been against the West for many years.

The situation in the region is not settled yet, but China might have an opportunity in Egypt, which if used wisely would represent a new era for Chinese presence in the Middle East. 


\section{Chapter Two:}

\section{The Rise of Islamists and Chinese Economic Interests}

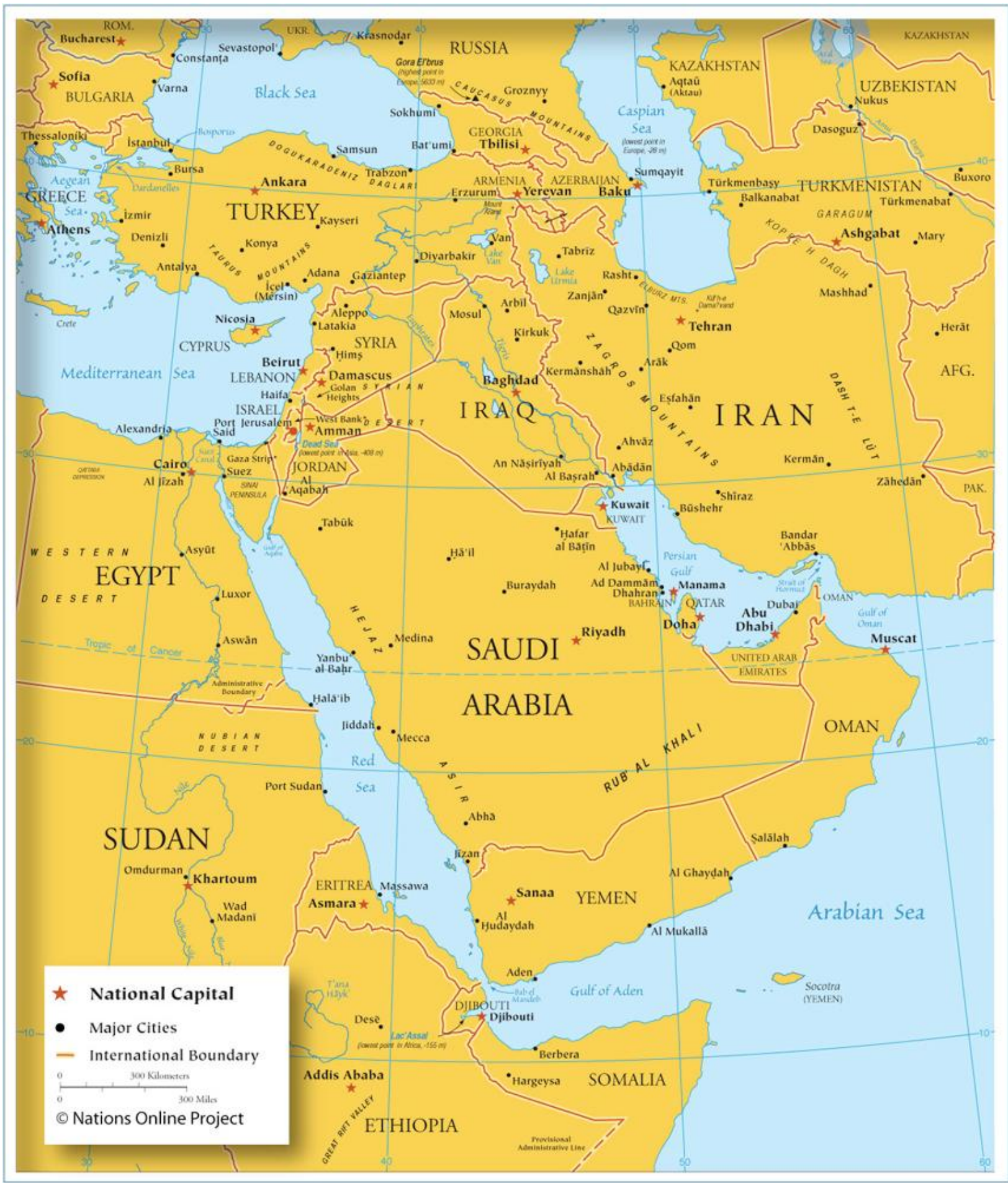

Source: Nations Online Project. 
Continuing economic growth of the Chinese economy is one of the core interests of China. Traditionally, China suffered from the unequal balance between coastal regions and inland in China in terms of economic development. The internal stability of China depends on continuing economic growth that prevents any internal uprising against China Communist Party. Hence, China has to keep and increase its exports as long as its economy depends on overseas demand rather than its domestic weak demand. China also should satisfy its increasing demand for energy especially oil and gas to meet its economic growth goal and that is the first core interest of China. The second core interest of China is keeping access to the sea lanes of communication through which it receives its imported energy resources and exports its products. The third core interest of China is preserving the territorial integrity of China and avoiding any threat in this regard, whether it is coming from the secessionist movements in Taiwan or Tibet or Xinjiang. The above three core interests of China are facing different challenges. First, the economic down turn in the European Union and the United States is affecting the ability of China to continue its economic growth at the same level due to their customers diminishing ability to import the same level of imports they used to have before. In addition, the domestic demand in China is weak due to the low saving rate between the Chinese people. The second challenge to China's core interests is the uncertainty surrounding the access to sea lanes. While China is importing around $77 \%$ of its oil and gas from Africa and the Middle East through the Malacca strait, China is vulnerable in any conflict with the US to shortage of energy supplies if the US navy blocked the Malacca strait. The US has strong naval capabilities compared to China especially after the declaration of the reengagement policy with Asia and the Pacific. China has sought to face this challenge through 
developing its naval capabilities and launching its first naval aircraft carrier, which will increase the influence of China in the Asia-Pacific region and also protect its interests regarding the offshore borders disputes with neighboring states. However, China will take a long time before its navy can develop its capabilities or become familiar with integrating the aircraft carrier warfare tactics into its navy. In the mean time, China decided to depend on offsetting the strategic balance with the US through depending on developing asymmetric power capabilities. Initially, China thought that it can develop land based missile capabilities that would deny the US navy access to the regional seas in East Asia especially the South and East China Sea. While China was successful in developing such missile capabilities to the extent that alarmed the US, it had to develop the necessary satellite capabilities for control and guidance of the missiles operations in case of a war in the future. But still such capabilities are not sufficient to offer China a full immunity from the US capabilities, because of the anti-satellite military capabilities of the US. The next option for China was to develop a strategy to avoid full dependence on the Malacca strait. This can be achieved through port access in neighboring countries with access in the Indian Ocean. China has sought port access in countries like Myanmar, Pakistan, Sri Lanka, and Bangladesh (Friedman 2012).

However, it was clarified in one of the recent information paper by the International Energy Agency (IEA) that even port access on the Indian Ocean will only decrease the dependence of China on Malacca strait through decreasing the percentage of oil and gas shipped through the strait, but will not offer full independence from the dilemma of the Malacca strait (Jiang and Sinton 2011: 35). 
The third challenge to China's core interests is the disturbances that it faces in its border districts like the Tibet and Xinjiang (Friedman 2012). This challenge will be discussed in details in the third chapter. The purpose of discussing the core interests of China was to clarify the relevance of China's economic interests in the Middle East within its overall strategy and foreign policy. Before discussing the energy and trade interests of China in the Middle East, the research will clarify the nature of the energy debate within China that influenced its global search for energy resources including in the Middle East.

China became a net importer of oil in 1993. "Between 1993 and 2002, China's oil consumption surged from 2.9 million barrels per day (b/d) to 5.4 million b/d, while oil production only grew from 2.9 million b/d to 3.4 million b/d over the same period. In 2002, the share of oil consumption constituted by imports was 37 per cent". The main participants about the debate of energy security inside China included the Chinese oil companies, the National Development and Reform Commission, State Economic and Trade Commission (SETC) (eliminated in March 2003), the Ministry of Foreign Affairs, and the Military (Downs March 2004: 21 -24).

The Chinese oil security strategy outlined in 2002 called for a number of measures to ensure China's control over its supplies, including investment in overseas oil fields, the construction of a strategic reserve system, shutting in oil fields in Western China for emergency use, and the development of Chinese naval and air forces to protect energy supplies. Chinese analysts consider the main sources of energy insecurity are oil prices volatility with the resulting inflation and physical supply disruptions. Many Chinese analysts are also worried about the prospect of US disrupting oil supply lines to 
China in case of conflict and they are not satisfied with the free riding model on the US protection of sea lanes, besides their concerns about the US putting pressure on oil exporting countries to limit China's access to oil resources (Downs March 2004: 25 $32)$.

During the internal debate in China on energy security, there were certain measures proposed to enhance energy security including strategic petroleum reserve, investment in overseas oil fields, the construction of transnational pipelines, and oil diplomacy. Although, there are disagreements internally over the strategic petroleum reserve based on cost and effectiveness of building the reserve (Downs March 2004: 32), it seems that China has decided to build its reserve, which will meet 90 days net import demand (Kennedy 2010: 141). At that time, it was contemplated that China would deal with the issue of energy security depending on three factors. First, the extent to which decision makers perceive the global energy markets as reliable source of low cost oil supplies. Second, China's perception of its relationship with the US and its allies. Third, the relationship between the Chinese leadership and the Chinese oil companies (Downs March 2004: 40 - 41).

In May 2005, Ma Kai, Chairman of the National Development and Reform Commission (NDRC) defined four elements to achieve energy security, which are energy diversification, conservation, renewal, and cooperation. Meanwhile, his deputy, Zhang Guobao, elaborated three strategies in this regard. First strategy is the abandonment of all-out economic growth and readjustment of the industrial structure. Second strategy is the development of alternatives to oil and reduced dependence on oil imports. Third 
strategy is the dual emphasis on development and conservation with priority on conservation (Yao September 2006: 175).

Accordingly, the Chinese energy security strategy involves five goals. The first is to ensure adequate oil supplies. The second is to make sure that the supplies are reliable. The third is the development of diversified energy sources. The fourth is to ensure reasonable energy costs. The fifth is to provide sufficient energy supplies at a sustainable long term environmental cost. To achieve the above goals, the Chinese government adopted a mercantilist approach, which emphasizes the role of the government in implementing economic measures and political initiatives for energy security, instead of adopting the liberal approach, which emphasizes the role of the market in satisfying the Chinese energy needs (Yao September 2006: 175 - 176).

China's need for energy has influenced its foreign policy through encouraging and supporting its companies to gain access to oil and gas resources all over the world. The Chinese need for energy inclined politicians to cooperate with business leaders to put plans for acquiring access to new resources. Developing countries are also getting benefits like using untapped resources or gaining leverage to negotiate better deals with older customers (Zweig and Jianhai 2005: 25 - 26).

However, the IEA information paper cited above considered that the relationship between the Chinese government and the National Oil Companies (NOCs) are complex. While the government has big percentage of shares in NOCs, but there are evidences that in certain cases the management in NOCs have taken decisions that were built on market considerations rather than government policy considerations (Jiang and Sinton 2011). 
Others also criticized the role of Chinese investments in the Third World Countries especially in Africa, because it does not take into consideration the good governance aspects like the Western investments in those countries, and the research will elaborate more on this issue later on in this chapter.

The influence of China's need for energy on its foreign policy and the subsequent success to acquire equity shares and equity production in different countries had raised concerns in the US about the rise of China. For example, China has established the China-Africa Cooperation Forum (CACF) in 2000. China cooperated also with Latin America and the Caribbean and 40\% of China's outgoing FDI went to Latin America in 2004. The US has concerns also about cooperation between China and rogue states like Iran, which undermine the US policy against them. Although, in certain cases like Sudan, which will be explained later on, the Chinese interests may be at risk, if it depends on unstable regimes. China has reportedly stationed 4000 non-uniformed forces to protect its interests there after the independence of South Sudan and the eruption of violence with the north (Zweig and Jianhai 2005: 26 - 32).

In Fact, the Chinese debate about energy security was part of an international concern especially between the major importers of oil and gas. The debate called for a new concept of energy security, which takes into account the rapid evolution of the global energy trade, supply-chain vulnerabilities, terrorism, and the integration of rising economies into the world market. The current energy security system was established after the 1973 Arab oil embargo. Its key element is the International Energy Agency (IEA). IEA has an emergency system in case of energy supply disruption, which was 
used twice only. The first instance was on the eve of the Second Gulf War in 1991. The Second instance was in autumn 2005 after the Hurricane Katrina (Yergin 2006: 70 - 75).

According to experience energy security involves several elements. The first is diversification of supply. The second is resilience, i.e. security margin in the supply system, like strategic reserve, spare production capacity or adequate storage capacity along the supply chain. The third is recognizing the reality of integration of the oil market and hence the stability of the market. The fourth is the importance of information about the market (Yergin 2006: $75-76$ ).

The new developments in the field of energy show the need to expand the energy security system in two dimensions. The first dimension is the globalization of the energy security system to include China and India. Yergin considered that there is no conflict between China and the US over resources. China is producing overseas $10 \%$ from the daily production of one of the major oil companies. Rather the conflict is concerning dealing with rogue regimes like Iran. After all, China or India exploration is important because it means more energy supplies to the market. The second dimension is concerning the entire energy supply chain, which needs to be protected (Yergin 2006: 76 $-81)$.

Andrew B. Kennedy referred to the new energy security debate in China and the new developments in this regard. He mentioned that due to the rising importance of China in the energy market, China started to participate in the meetings of IEA as a 'major dialogue partner' to avoid the strict conditions on membership put by the organization. He clarified also that there are differences about whether China should 
proceed and build aircraft carriers, after its first aircraft carrier was launched to secure access to sea lanes for its exports and imports. However, others are supporting the access denial strategy instead of sea control strategy (Kennedy 2010: 141 - 142).

The most important development in China's debate about energy security is focusing on the internal dimension of energy security (the demand side), especially the inefficient heavily polluting energy system, instead of the traditional focus on the supply side through securing supplies. In 2006, President Hu Jintao proposed at the G8 summit in St Petersburg a new energy security concept. He called for greater international cooperation to increase oil and gas supply; the need to control domestic demand; and for sustainable development of human society. In 2007, China set a goal to generate $15 \%$ of its energy from renewable sources by 2020 , through mandates on power companies, investments in the power grid, and subsidies for consumers. China has begun also to set targets for its greenhouse gas emissions. But still the central government's ability to govern the energy sector is too weak, due to the lack of a Ministry of Energy to monitor and ensure that the central policies are implemented (Kennedy 2010: 143 - 147). On August $22^{\text {nd }} 2012$, Xinhua News Agency has mentioned that according to a document released by the State Council, China will invest US $\$ 375.6$ billion in major energy-saving projects during the 12th Five Year Plan (2011 - 2015).

According to the above debate about energy security, the research now turns to discuss the energy and trade relations of China with the Middle East, before examining the effect of the uprising in the Middle East and the rise of Islamists on its interests. 
Until early 1990s, China used to depend on Southeast Asian producers for its oil needs, but due to increasing consumption of Southeast Asian producers, China started to look elsewhere. The Middle East provided China with several advantages in this regard, because of the proven reserves, idle supply capacity, and relatively low development and production costs (Calabrese Summer 1998: 356).

China's lack of military presence in the region forced it to depend on other tools to secure its interests like diplomatic contacts, trade, FDI, and arms sales, besides its influence in the UN and its relations with France and Russia, who usually are reluctant to the US hegemony. Since 1978, the internal changes inside China under the reform process emphasized the rise of external relations that serve economic growth and modernization at home. Accordingly, China had built diplomatic relations with all countries in the Middle East including American allies and anti-American states. This has reflected the pragmatism of China and the retreat of ideological elements in its policy towards the region (Yetiv and Lu Spring 2007: 201).

China established relations with Iran in 1970, Iraq in 1958, Emirates in 1984, Bahrain in 1989, and Saudi Arabia in 1990, although the first Sino-Saudi official meeting was in Oman in November 1985. Both countries signed a strategic oil partnership together in 1999. China cooperated also with the Gulf Cooperation Council (GCC). On May 27th, 1981, two days after the establishment of GCC, China established diplomatic ties with it. In 1983, China National Petroleum Corporation (CNPC) began to enter the Kuwaiti and Iraqi markets with limited contracts to offer labor and other services. During the period from 1992 to 1997, China's oil material and equipment exports to the Middle East grew 710 times. In 1992, GCC-China Trade Conference was established. In 1996, a 
consultative mechanism was established between GCC and China with consultations rotating each year between Beijing and Riyadh. Some analysts may consider that the cooperation between Riyadh and Beijing is partly because both countries are looking forward to check the influence of the US in the Gulf, especially as Riyadh may fear the US influence to change its political system and way of life even indirectly. China and Saudi Arabia signed in 1999 a strategic oil cooperation agreement. The trade volume between China and GCC increased from US $\$ 1.5$ billion in 1991 to US $\$ 33.7$ billion in 2005. By 2004, the GCC countries only apart from the Arab countries has become China's eighth largest trading partner, eighth largest export destination, and ninth largest source of imports (Yetiv and Lu Spring 2007: 201 - 207).

In addition, the establishment of diplomatic relations between China and Saudi Arabia was important for China, because China was struggling to emerge from the isolation after Tiananmen incident; the establishment of relations with Saudi Arabia was accompanied with severing relations with Taiwan which is a victory for "One China" policy; it also laid the ground for expansion of commercial ties with Saudi Arabia and open opportunities with the rest of the Gulf States (Calabrese Summer 1998: 359).

However, China's role in the Middle East was not easy especially in the beginning. In fact, China faced three challenges in the region in the early 1990s. The first challenge was the Iraq invasion of Kuwait. The second challenge was the aftermath of Kuwait liberation and sanctions against Iraq. The third challenge was china's relationship with Iran, which is still continuing until now. The 1990 Iraqi invasion of Kuwait posed a challenge for China, as it advocated in the beginning an Arab diplomatic solution to the crisis. China supported diplomacy over sanctions and sanctions over force. China 
supported the first ten UN resolutions against Iraq and stopped short of supporting the use of force by UN resolution no. 678 and refused to participate in the liberation of Kuwait. Kuwait responded by suspending US $\$ 300$ million development loans to China at that time in retaliation for abstention on the UN resolution no. 678. Some estimates about the loss of China because of the war are in excess of US\$2 billion in assets and earnings. Later on, China had also reservations on the sanctions and military strikes against Iraq after the war on the basis of Iraq sovereignty and territorial integrity. China raised also humanitarian and economic considerations for lifting the sanctions (Calabrese Summer 1998: $360-362)$.

But China moved gradually to acquire access to oil and gas resources and build its relations with the region. For example, in October 2004, China and Iran signed MOU in which China would develop Iran's Yadavaran oil field (the largest undeveloped oil field) in exchange for agreeing to buy 10 million tons of Iranian Liquefied Natural Gas annually for 25 years. This MOU was followed by critical oil and gas contracts in 2005 and 2006. In his first trip after assuming the throne, King Abdullah signed five major agreements in China on energy cooperation on January 2006. China and GCC had initiated FTA agreement negotiations during a GCC delegation visit to China in July 2004. During the visit, it was agreed to establish a joint economic and trade cooperation commission and launch a bilateral consultative mechanism (Yetiv and Lu Spring 2007: $205-206)$.

In 2009, Chinese oil companies, including National Oil Companies (NOCs), invested in 10 overseas acquisitions world wide for a total of US\$18.2 billion. In the same year, China has imported just under 4 billion b/d of crude oil, up 14\% from 2008, 
and the first year that China has imported more than half (51.3\%) of its consumption of oil. CNPC purchased 35\% stake in shells subsidiary in Syria. China was successful in accessing energy resources due to applying several policies like loans-for-oil, loans-forgas, and market-for-resource strategy. Through these policies and strategies, China was capable of accessing energy resources in resource rich countries in exchange for providing loans or allowing those countries to enter the huge Chinese market and gain economic benefits. The estimated value, for the Chinese share of overseas equity in oil exporting countries in Q1 of 2010, shows that $15 \%$ of the Chinese shares of overseas equity in oil are in Sudan, 6\% in Syria, and 3\% in Tunisia. China accounted for almost half the global oil demand growth in 2010, and will continue to account for half the global demand growth until 2015. In 2009, the top ten oil suppliers to China according to the volume of imports were Saudi Arabia, Angola, Iran, Russia, Sudan, Oman, Iraq, Kuwait, Libya, and Kazakhstan. According to Xinhua New Agency, China's crude oil imports by region in 2009 were as follows: the Middle East (47\%), Africa (30\%), Russia/FSU (11\%), Western Hemisphere (7\%), and Asia-Pacific (5\%) (Jiang and Sinton 2011: $9-18)$.

China's access to oil and gas resources in the Middle East has faced challenges in some countries compared with what it achieved in the GCC. The main challenge China is facing in the energy industry is in Sudan. China National Petroleum Corporation (CNPC) began operating in Sudan in 1995 (Liangxiang Spring 2005: 3 - 10). From the beginning, China had to deal with Sudan like other regimes in Africa through offering assistance to a regime that is criticized by the West for being a non-democratic regime. Although, Sudan is considered a rogue regime like Iran by the West and especially the US, Iran is more 
stable internally compared to Sudan. The latter has been involved in a civil war against the south for decades before the south declared independence last year.

China usually did not care about governance issues, whenever it dealt with regimes in Africa or the Middle East. China transferred weapons to Sudan before independence of the south to save a share in exploitation of oil reserves. CNPC owns the largest share (40\%) in Sudan's largest oil venture, the Greater Nile Petroleum Operating Company. CNPC receives around 150,000 b/d from the project. It covers 50,000 square miles in South Sudan, but the contract was signed before independence of South Sudan. The project is expected to produce 15 million tonnes of crude oil annually with proven reserves of 220 million tonnes. CNPC construction wing has built the 930 mile pipeline to the Red Sea and a refinery near the capital of Sudan Khartoum. China has welcomed the peace agreement between the north and the south given that the oil agreement signed by Khartoum will be respected. (Taylor 2006: 949 - 950).

But the differences between Sudan and South Sudan, over the demarcation of borders line and fees to be collected by Sudan for exporting the oil of South Sudan through its port on the Red Sea, have led to a difficult situation for China. China is trapped between Sudan and South Sudan as both parties are trying to put pressure on China to take its side, while China adhered traditionally to non-interference in the internal affairs of other nations. China is the biggest player in oil industry in both countries as it has stakes in the main oil fields in the South and in the pipelines and infrastructure in the north. But South Sudan officials threaten that if China does not align its interests with the South, they will seek out Western oil companies (Raghavan and Higgins 2012). 
The other side of Chinese economic interests in the region is trade. The main forum, through which China is dealing with the region as a whole to advance its interests, is China-Arab States Cooperation Forum. According to the website of the forum, on January 30th, 2004, Chinese president Hu Jintao has visited the Arab League in Cairo, where he met with the then Secretary General Amr Moussa and the Arab States permanent representatives and after the meeting both sides declared the establishment of the "China-Arab States Cooperation Forum".

The forum aims to enhance dialogue, cooperation, and development between both sides. The forum includes the establishment of a "Ministerial Council" for foreign ministers and attended by the Secretary General of the Arab League. The Ministerial Council meets every two years and the meetings are hosted alternatively between China and the Arab League or an Arab State. The forum also convenes on the level of "Commission for Senior Officials" every year and hosted alternatively between the two sides. There are other divisions and workshops that developed gradually within the forum to enhance cooperation between both sides in different fields like the Conference of Businessmen and the Conference of Energy.

The fourth level of cooperation within the forum is the "Liaison Group", which follows up the implementation of the resolutions and recommendations issued by the Ministerial Council and the Commission of Senior Officials. The Liaison Group consists of the Chinese Embassy in Cairo, the Council of Permanent Representatives of the Arab States to the Arab League, the Delegation of the Arab League in Beijing, and the office of the Chinese Secretariat of the Forum in the Department of West Asia and North Africa at the Chinese Ministry of Foreign Affairs. 
The trade figures between China and the Middle East indicate that in the first decade of the 21st century, the volume of trade between China and the Arab States increased eight times from US $\$ 20.3$ billion in 2001 to US\$145.4 billion in 2010. In spite of the international financial crisis the volume of trade between both sides increased to US $\$ 195.9$ billion in 2011 with $34.7 \%$ increase compared to 2010 .

The two sides declared, during the fourth Ministerial Council meeting in 2010, the establishment of strategic relations based on full cooperation and joint development. Recently, the fifth Ministerial Council meeting was hosted by the Hammamet city in Tunisia, during the period from $29^{\text {th }}$ to $31^{\text {st }}$ May, 2012. The theme of the meeting was "Deepening Strategic Cooperation and Supporting Joint Development". The meeting sought to achieve three goals. The first goal is deepening strategic cooperation between China and the Arab States and developing the forum mechanisms. The second goal is determining the fields of priorities and cooperation projects for the next two years and the implementation program in this regard. The third goal is exchanging opinions and reaching consensus between both sides about regional and international issues.

The meeting has issued the implementation program of cooperation for the period from 2012 to 2014. The program included agreed upon steps to foster relations between both sides. The program included areas of cooperation like increasing the volume of trade between both sides to US $\$ 300$ billion by 2014 ; establishing settlement process for trade disputes between both sides, besides the present bilateral settlement process; establishing banking institutions in China and the Arab States according to the local law and facilitating bilateral trade and investment; encouraging the financial institutions to support and facilitate investment, constructions, and trade between both sides; and China 
will host training programs for 5000 Arab nationals in different fields during the period from 2012 to 2014.

The uprising in the Middle East has removed at least three regimes until now and created instability in the three countries with varying degrees between them. The research will focus on the example of Libya to examine the effect of the uprising on Chinese economic interests. Although this example has its own limitations because the relations between China and Libya before the uprising were not strong with wide entrenched interests, but this example can refer to the challenges that China may face with the new regimes or interim-governments in the aftermath of the uprising.

According to Xinhua News Agency, during the period from $4^{\text {th }}$ to $8^{\text {th }}$ February, 2012, a Chinese delegation visited Libya to discuss the participation of Chinese companies in the post-war reconstruction in Libya and discussing the problems facing the Chinese companies to return again to Libya to continue its projects in different Libyan cities. The problems included granting visas for the Chinese labor, opening bank accounts for the companies, some legal aspects concerning the signed contracts, importing raw materials, customs procedures, and losses of belongings of the Chinese companies in Libya in the aftermath of the uprising.

Xinhua clarified that the Chinese companies before the uprising were implementing many major projects with total value more than US $\$ 20$ billion. The companies have finished about $80 \%$ in some projects. Libyan official at the Housing Ministry stated that the priority in the future will be given to countries that supported the rebels against Gaddafi regime and that the Chinese companies are welcome to return to 
Libya but without pre-conditions, besides Libya would review all the previous contracts to confirm the absence of any corruption cases related to the contracts and that those projects satisfy the needs and priorities of Libya.

Further Xinhua stated that on February 16th, 2012, the spokesman of the Chinese Ministry of Foreign Affairs declared that it is difficult to set a date for the return of the Chinese companies to Libya, because there are issues to be discussed first with Libya like labor personal security, compensations, and payments of the companies. On March 7th, 2012, Chinese Minister of Trade declared that China requested from Libya to compensate the Chinese companies, which were working in Libya when the civil war erupted after the uprising due to the losses that they suffered. The Minister clarified that China has no investments in Libya, but construction projects only, with housing projects worth more than US\$10 billion. He added that those projects, which were finished or almost finished, were bombarded during the civil war. He added that the companies cannot return to Libya now due to security concerns.

However, it seems that diplomatic contacts continued between both sides to settle the differences between them. Xinhua published the news about the visit of the Foreign Minister of Libya to China during the period from 9th to 13th June, 2012. He declared during the visit that he wishes the participation of the Chinese companies in the reconstruction of Libya. He added that Libya will protect the legal rights and interests of the Chinese companies in Libya.

He also clarified that the Libyan interim-government has established a special committee to investigate the damage and losses of foreign companies including the 
Chinese ones and to consider the necessary compensations in this regard. He expressed his wishes that the Chinese companies would return to Libya as soon as possible, while the interim-government in Libya will offer the necessary circumstances for its return.

It seems that the change in the Libyan position can be attributed to different reasons like the need to avoid any legal settlements that may force Libya to pay expensive compensations; the importance of having good relations with China to benefit from its financial capabilities in the reconstruction of the country; China is a good source of loans which necessitates keeping relations with it. On the other hand, China's diplomacy succeeded in dealing with the problem through including several articles in the implementation program of the fifth Ministerial Council of the China-Arab States cooperation Forum that facilitate the settlement of the differences through including articles concerning a settlement process for disputes, the commitment to facilitate trade and investment, and offering the necessary banking facilities. It seems also that China succeeded in containing the situation and reaching to solution with Libya in a relatively short period of time and neutralizing any negative aspects of its policy of noninterference in the internal affairs of other countries which might have led the rebels in Libya to consider it a tacit support for the previous regime. But still, it is not clear the extent of rapprochement between China and the rebels in Libya, who received the support of the West against Gaddafi and who is expected to pay back one way or another for the Western support. The picture will be more clear in the future, when the Libyan authorities start to develop its oil fields, then we will be able to see whether the contracts will go to the West and especially the US or to China. 
The gas agreement between Egypt and Israel is another example of the challenges that may face China in the region after the uprising, if it wants to extend its influence beyond its traditional partners in the region. Although, China is not related directly or indirectly to the gas agreement between Egypt and Israel, but the gas agreement is a good example of the way the new regimes may deal with its previous commitments towards the West and its allies in the region (Israel) and the ability of the new regimes to build relatively stronger relations with China.

The published details about the gas agreement are very limited with two different points of views about whether the agreement included corruption on behalf of the Egyptian government. The opposition saw the agreement involved corruption related to the low price of selling the gas to Israel through an intermediate company called East Mediterranean Gas Company (EMG). EMG Company has share holders from Egypt Israel and the US. On the other hand, the previous regime in Egypt saw the agreement as a political leverage for Egypt against Israel, because the exported gas would constitute $40 \%$ of Israel consumption of gas. However, there was a strong popular opposition in Egypt for the agreement because of Israel policies against the peace process.

After the uprising it was expected that the Supreme Council of Armed Forces (SCAF) will cancel the agreement in response to the popular opposition. But neither SCAF nor the interim-government were capable of taking such a decision. While the members of the previous regime are prosecuted for selling the gas at a low price, the new regime decided only to negotiate with Israel to raise the price of gas, although the pipeline transferring the gas was not functioning very well since the uprising due to several attacks by Islamist militants on it. 
However, later on the Egyptian interim-government decided to cancel the agreement that was in fact signed with EMG Company not with Israel. Egypt declared that the cancellation was due to overdue payments by EMG Company during the last period and that there are no political reasons behind the decision. Although there are doubts about the nature of the decision, it shows that the interim regime was not capable of changing the binding commitments by the previous regime, unless there is a sufficient legal reason to support the change, because the new regime is aware that it may face an arbitration case that can oblige it to pay expensive compensations for cancelling the agreement.

There are several policy implications for China in this regard. China has to deal with the present situation in the Middle East very carefully to avoid damaging its economic interests in the region. China should not expect that the changes in the Middle East will necessary entail positive implications for it. In the short run, the interim regimes are not capable of identifying a clear policy for their countries. On the other hand, the newly elected regimes will have to deal with the complex nature of the situation and to balance its relations between the West, who supported it, and China as a new rising power with financial capabilities useful for the reconstruction process. But the extent to which China will be capable of building stronger relations with the new regimes will depend on several factors like the nature of the future regimes ideologies (whether they are Islamists against the West or not); the relations between the new regimes and the West; and the possibility of changing the commitments made by the previous regimes by the newly elected regimes. 


\section{Chapter Three:}

The Rise of Islamists and Chinese Territorial Integrity

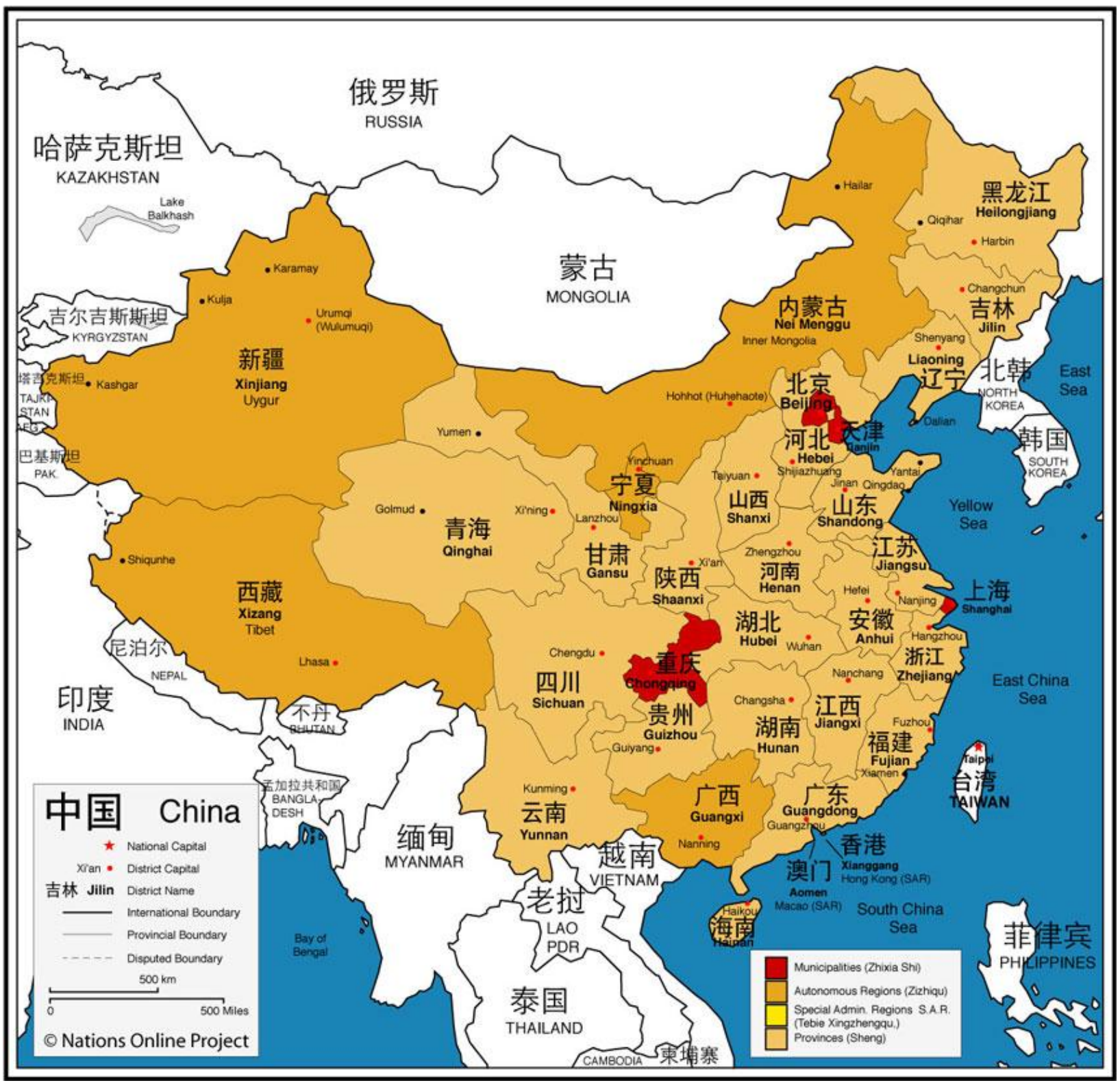

Source: Nations Online Project.

The research has clarified in chapter one and two that China has three main strategic core interests. The first interest is maintaining economic growth through increasing exports. The second interest is free access to sea lanes for energy imports and 
trade exports. The third interest is maintaining control over buffer zones to achieve security, especially in Tibet and Xinjiang, which can be referred to as preserving the territorial integrity of China (Friedman 2012).

In fact, the case of Xinjiang is very important, because it is not only related to the third of goal of preserving territorial integrity of China, but also achieving energy security through projected pipelines from Central Asia through Xinjiang to east China, which will lead also to decreased dependency on sea lanes. However, Xinjiang has been restive for decades with a big proportion of ethnic minority groups especially the Muslim Uyghur. Accordingly, this chapter will discuss the situation in Xinjiang and the effect of the rise of Islamists in the Middle East after the uprising on China's sovereignty over Xinjiang and its territorial integrity.

In $104 \mathrm{BC}$, the Western Han Dynasty occupied the region and it became for the first time part of China. In 1759, Xinjiang was reunified after the Qing Dynasty of the Manchu defeated the rebellions. In 1844, the Xinjiang province was established and incorporated in the Qing Empire. During the Republic of China era, Xinjiang was largely controlled by warlords. Two short-lived East Turkistan Republics existed in Xinjiang in 1933 and during the period from 1944 - 1949. In 1949, the People's Liberation Army (PLA) entered Xinjiang and it became formally a province of the new established People's Republic of China (PRC). The Xinjiang Uyghur Autonomous Region (XUAR) was established on January 10th, 1955. Xinjiang was relatively quiet during the first four decades of the PRC, but during the Cultural Revolution some disturbances occurred because of the restrictions on religious and cultural aspects, through for example the activities of the East Turkistan People's Revolutionary Party from 1967 to the end of the 
Cultural Revolution. After the beginning of the Reform and Open-up Policy, some religious activities resumed, and Pan-Islamism and Pan-Turkism rose once again. In the 1980s, the influential unrests in the province included the Kashgar riots in 1980 and 1981, and the Urumqi demonstrations in 1985, 1988, and 1989. After the collapse of the Soviet Union and the establishment of independent states in Central Asia, the hope of East Turkistan ignited again. In the 1990s, the Eastern Turkistan Movement launched several attacks in the province. The influential disturbances in the 1990s included the Baren riot in 1990; the Yining disturbances in 1995; the Hotan event in 1995, the Aksu incidents in 1996; the Yining insurrection in 1997, and the Urumqi disturbances in 1999. During those disturbances 162 citizens were killed and over 440 were wounded. Following the 9/11 attacks, China began to pay attention to terrorism intended for separatism and international cooperation against terrorism was put on China's diplomatic agenda. After the invasion of Afghanistan by the US, Xinjiang was relatively quiet for years until 2008, when the separatists initiated activities to disrupt the Beijing Olympic Games in Urumqi, Kashgar, and Kucha. On the $5^{\text {th }}$ of July 2009, the most violent riots erupted in Urumqi. By the $17^{\text {th }}$ of July 2009,197 people were dead, over 1700 were injured, with 331 shops and 1325 vehicles were destroyed or burned, and many public facilities were damaged. Several attacks were launched overseas also. In March 1997, 'East Turkistan' groups attacked the Chinese embassy in Turkey and the Chinese consulate general in Istanbul. In March 2000, Nighmet Bosakof, president of Kyrgyzstan 'Uygur Youth Alliance', was shot dead because he refused to cooperate with the 'East Turkistan Liberation Organization'. In May 2000, members of the 'Uygur Liberation Organization' extorted US\$100,000 as ransom after kidnapping a Xinjiang businessman, 
murdered his nephew, and set the Bishkek Market of Chinese Commodities on fire. In July 2002, Chinese workers were attacked in Pakistan after handing over senior Muslim leaders arrested in Kashmir including the Uyghur leader Ismail Kadir. "In 2002, the United Nations Security Council added the 'East Turkistan Islamic Movement' (ETIM) to its sanction list of terrorist groups. The East Turkistan organizations now include: the East Turkistan Islamic Movement (ETIM), the East Turkistan Liberation Organization (ETLO), the World Uyghur Youth Congress (WUYC) and the East Turkistan Information Center (ETIC). In 2004, the 'East Turkistan' forces patched together the World Uyghur Congress (WUC)" (Hao and Liu 2012: 208). The standard of living in Xinjiang improved remarkably. For example, in 2008 the per capita net income of farmers in Xinjiang was 3503 Yuan, which is 28 times more than that of 1978. According to the State Council, from 1950 - 2008 the central government invested 386.23 billion Yuan in Xinjiang, accounting for $25.7 \%$ of the total investment in the region. Since the establishment of Xinjiang Uyghur Autonomous Region (XUAR) in 1955 until 2008, the region received 375.202 billion Yuan in subsidies. During the period from 1978 to 2008, the per capita GDP in Xinjiang grew 28 times and ranked 15 among 31 provinces in China in 2008. In 2008, the total population of Xinjiang was 21.308 million. The three largest ethnic groups were the Uyghur (9.832 million), Han (8.363 million), and Kazak (1.510 million) (Hao and Liu 2012: 206 - 208).

Xinjiang has an important location in Eurasia and represents one sixth of China's territory as it spans over 1,660,001 square kilometers. China has three groups of interests in Xinjiang as follows: 


\section{$\underline{\text { Political and Security Interests: }}$}

The British geographer Sir Halford J. Mackinder called Central Asia the 'geographical pivot of history' or the 'heartland'. In 1950, Owen Lattimore considered Xinjiang a new center of gravity in Asia between China, the Soviet Union, India, and the Muslim Middle East. Zbigniew K. Brzezinski referred to the importance of Eurasia in the post-Cold War era within the geostrategy of the US. Nowadays according to geopolitics, Xinjiang and Central Asia are the center of the new great game between the great powers like China, Russia, India, the US, NATO, and Shanghai Cooperation Organization (SCO) countries. Different powers are interested in Central Asia. Russia seeks to restore its influence in the region, like the Soviet era, as its backyard. NATO insists on expansion to the East. China is a rising power in the East. India is a rising power in the South. The US is interested in the region for its energy resources and the campaign against terrorism. Chinese interests have been negatively affected from the increasing presence of the US after 9/11 in Central Asia. Driven by the US, NATO increased its presence in Central Asia. Within NATO's Partnership for Peace (PFP) program, the Central Asian Battalion (CentrazBat) was established in 1995 including Kazakhstan, Kyrgyzstan, and Uzbekistan, besides the annual military maneuvers between the US and the three countries. The US and Europe have gained also base access rights in the region. The above great powers also represent different cultures, which can be reflected on conflicts between states in the region and within states between ethnic groups. The direct international challenge for China in Xinjiang is Pan-Islamism and Pan-Turkism. Turkey is the center of PanTurkism and a base for Pan-Islamism. Historically, the Western colonists used to call Central Asia as 'West Turkistan' and Xinjiang as 'East Turkistan'. Turkey was the first 
state to recognize the independence of the Soviet Central Asian republics, and the first country to open embassies in them. The Central Asian countries are Muslim Sunni and speak Turki except Tajikistan. The same situation is also in Xinjiang where most ethnic groups are Sunni Muslims. Tajikistan and the Tajik people in Xinjiang are an exceptional case because they speak Persian and are Muslim Shia like Iran. Hence, Xinjiang is highly important for China and if it became independent, China would lose its access to Central Asia and Eurasia. China would also face internal instability as other regions like Tibet and Inner Mongolia might follow Xinjaing, besides China's international status will be severely negatively affected. (Hao and Liu 2012: 209 - 211).

\section{Energy and Resources interests:}

Xinjiang is highly important for China in terms of energy and mineral resources. "In 2008, Xinjiang ranked second in China in oil production, generating 27.22 million tons of crude oil; and it ranked first in the production of natural gas, producing 24 billion cubic meters" (Hao and Liu 2012: 211). By 2008, Xinjiang had a network of pipelines to transport oil and gas to eastern China with total length exceeding $4000 \mathrm{~km}$. Xinjiang also contains 115 of 147 raw materials found in China, besides the large industrial base in the province. China's energy needs are increasing, Although, China can import oil and gas from different regions in the world, but the two most regions with huge capacities are the Middle East and Central Asia. Xinjiang is connected to the first culturally and the second geographically. Proven oil reserves in Central Asia are estimated between 16.9 billion barrels and 33.4 billion barrels, while the proven natural gas reserves in the region are estimated between 177 and 182 trillion cubic feet. Developing relations with Central Asia 
is also important for China, because it wants to decrease dependency on Malacca strait in the long run (Hao and Liu 2012: 211 - 212).

\section{Trade Interests:}

Xinjiang is also important to China in terms of trade, as it connects China with Central Asia. In fact, two thirds of the trade between the region and China takes place with Xinjiang. In addition, China has growing trade relations with the Middle East, which is culturally connected to Xinjiang (Hao and Liu 2012: 212 - 213).

In spite of, the economic development in Xinjiang and the strategic importance of the province to China, but the unrest and ethnic tension in Xinjiang are continuing due to several reasons.

First, historical factors connected to ancient riots and secessionist movements in Xinjiang. The historical ethnic conflicts buried seeds of hatred between different ethnic groups, especially the Uyghur, Han, and Hui. The separatist regimes in history provided also historical source for today's East Turkistan Movement. Second, economic grievance as the Uyghur people are usually suffering from lower standard of living compared to the Han people especially in terms of per capita GDP. The province is divided along ethnic lines in terms of jobs especially the professional and technical jobs with high salaries. The cities that have the largest proportion of Uyghur are the ones that mainly witnessed riots and disturbances. Third, Chinese law specify the rights of minorities especially the 1982 constitution and the May 1984 law on Regional Autonomy for Minority Nationalities. However, there are problems related to the degree of autonomy offered to ethnic groups. For example, decisions by autonomous regions in China are subject to 
revision by higher levels of government. Religious freedom is also facing many restrictions like prohibiting Communist Party members and cadres in government from practicing any religion, and limiting the freedom of conducting prayers in mosques. Fourth, cultural grievances include also the encouragement of Han Chinese by central government to settle in Xinjiang. The stated goal of the central government for Han migration was to facilitate economic development, not to force demographic change in the province. The education system also reflects bias towards Han culture. Fifth, the international factor also is behind the ethnic tension in Xinjiang. Pan-Turkism and PanIslamism are advocated by separatist groups in Xinjiang, which gained momentum especially after the Reform and Open-up Policy in China. The separatist groups have also received training and funding from $\mathrm{Al}$-Qaeda. On the other hand, great powers like the US, who are looking for projecting influence in Central Asia, are supporting Uyghur human rights and pro-democracy organizations. The National Endowment for Democracy (NED), which receives funding from the congress, granted financial support of US\$731.306 to such organizations. Besides Radio Free Asia (RFA) in the US, that is broadcasting to Xinjiang through Uyghur language on issues like human rights and religious freedom...etc. Sixth, environmental grievances include the extensive use of resources in the energy sector and agriculture without regard to sustainable development or the ecological effects. Another environmental grievance is the nuclear tests carried out by Beijing in Xinjiang. The sole nuclear test site in China is in Lop Nor, Xinjiang. The province suffered previously from radioactive fall out. China has carried out 40 nuclear explosions above and below ground at Lop Nor between 1964 and 1996. Some of them were 300 times stronger than the bomb dropped on Hiroshima in World War two. 
Seventh, human rights abuses were mainly committed in recent years within the 'Strike Hard, Maximum Pressure' campaign launched by Beijing in 1996 against separatism in Xinjiang. Eighth, other grievances include the deteriorated health services to Uyghur, which is reflected in their low life expectancy compared to any ethnic group in Xinjiang. Other complaints, which can be raised by other ethnic groups also, include the repressive political climate, censorship, stringent family-planning policy...etc., (Hao and Liu 2012: 213 - 221, Mackerras 2001: 290, Reed, J. Todd and Raschke, Diana 2010: 18 - 29).

However, China has adjusted or changed its policy towards Xinjiang to maintain stability in the province and its territorial integrity, especially after the riots on July 5th, 2009. On 24th of April 2010, the Secretary of the CPC in Xinjiang Wang Lequan was replaced by Zhang Chunxian, and the politbureau of the CPC has decided that the economic and social improvement should be given a priority. This was considered a shift from the policy of Wang Lequan, who gave priority to stability. The new policy will deal with development and stability equally. During the period from 17th to 19th of May 2010, the first Central Work conference on Xinjiang was held in Beijing to implement the necessary policies to improve the standard of living in Xinjiang; decrease the relative disparity between ethnic groups, and promote more religious freedom. In the mean time, China cooperated with the US against terrorism after $9 / 11$ and also signed agreements within Shanghai Cooperation Organization (SCO) that allowed China to justify its fight against separatist groups within the framework of fighting terrorism. China also supported UN resolutions against terrorist groups and organizations, especially the UN resolution 1373 (Hao and Liu 2012: 221 - 224). For example, on $5^{\text {th }}$ of July 2000, China established with neighboring Central Asian states, (Russia, Kazakhstan, Kyrgyzstan, and 
Tajikistan), a joint anti-terrorist center to combat incursions by extremists and drug traffickers. On June 2001, Uzbekistan joined the regional regular meetings. The same meeting witnessed the establishment of the SCO (Mackerras 2001: 295). China's foreign policy towards Central Asia aims to prevent any external support from neighboring countries to insurgency groups in Xinjiang and forestall any prolonged presence of US military bases in the region (Blank 2003: $134-135$ ).

Although China supported the US and the West on the anti-terrorism campaign after $9 / 11$, but differences have emerged between both sides due to different approaches to counter-terrorism. The differences were mainly about the definition of terrorism and effective reactions to terrorist events. The current phase of resistance started in 1990 with rebellions in Baren village and series of incidents occurred since then. The 1990s also witnessed increased contacts between radical militants in Western China and overseas extremist groups, including a reported meeting in the city of Kashgar of Xinjiang in 1993 between radical Uyghurs, Kashmiris, Afghanistan Mujahideen, and Hezbollah in Lebanon. China responded in the mid-1990s with a policy later on named 'Strike Hard, Maximum Pressure' against separatism and terrorism. The Chinese government also made a link between extremist and separatist groups in Western China and Al-Qaeda. In January 2002, China released a report linking the East Turkistan Islamic Movement (ETIM) and international terrorist organizations including Al-Qaeda. The report claimed that the ETIM leadership met with Osama Bin Laden in 1999 and that the group was training with Al-Qaeda in Afghanistan. The report also mentioned the attacks carried out by ETIM and sympathetic groups. Although the strength of the links of ETIM with AlQaeda is disputed, there were evidences of meetings between both sides and also there 
were 22 Uyghur nationalists detained in Guantanamo Bay prison after being apprehended in Afghanistan. However, some of them were released to third countries instead of China later on, due to concerns about human rights in China. In 2002, then-US Deputy Secretary of State Richard Armitage declared that the US agreed to identify ETIM as terrorist organization, although human rights groups argued that there is little evidence linking the ETIM to Al-Qaeda or that it represents a threat to American interests. The leader of ETIM Hassan Mahsum was reportedly killed in South Waziristan, by Pakistani forces in October 2003. On January 2010, fifteen terrorists from Western China, two of whom were ETIM, were reportedly killed by American air strikes in Afghanistan (Lanteigne 2012: 89 - 94).

The ETIM website traces the origin of the group to the Turkistan Islamic Party formed in 1940 by Abdul Azeez Makhdoom, Abdul Hameed, Abdul Hakeem, and other scholars. Throughout the 1940s and 1950s, the group engaged in activities against the central government military forces. Around 1956, the group changed its name to the present name East Turkistan Islamic Movement (ETIM). After defeat in 1956, the group went inactive until the 1980s. In the late 1980s, ETIM was revived by Dia Uddin bin Yousef. On April 5 - 6 1990, the group led a rebellion in Baren Township, Akto County, Xinjiang. Hassan Mahsum was arrested during that rebellion and imprisoned from May 1990 to November 1991, then he was imprisoned again from late 1993 to early 1996 on terrorism charges, and imprisoned for the third time in August 1996 in Strike Hard campaigns, but he left Urumqi in January 1997 after his release. Hassan Mahsum revived ETIM about September 1997, after the death of Abdul Hakeem in 1993. ETIM moved its headquarters to Afghanistan in September 1998 and established training camps there. 
After his death in October 2003 in Angoor Adda, South Waziristan, Pakistan by a joint US - Pakistani operation, Abdul Haq Al-Turkistani became the new leader of ETIM, and it is likely that he is the same person named Abdul Haq, who used to run the day-to-day operations of ETIM camp in Afghanistan in 2001. Abdul Haq Al-Turkistani heads also the ETIM's Shura Council, which consists of the emir, deputy emir, head of religious education division, head of military affairs division, and head of the information center, and may be other reported divisions like intelligence and logistics divisions (Reed, J. Todd and Raschke, Diana 2010: 47 - 50).

The US included ETIM on its finance blacklist on September 3, 2002, and added Abdul Haq, on April 20, 2009. The US also included ETIM on immigration blacklist called Terrorist Exclusion List (TEL) on April 29, 2004. But the US did not include the group on the State Department's high-profile Foreign Terrorist Organizations (FTO) list. The UN blacklisted ETIM under UNSC resolutions 1267 and 1390 on September 11, 2002, at the behest of the US, China, Afghanistan, and Kyrgyzstan. The UN added Abdul Haq to its blacklist on April 20, 2009. However, many analysts consider the US blacklisting of ETIM as part of policy trade off with China on other issues, but the US officials deny this claim. On the other hand, the attacks and statements of ETIM confirmed its perception internationally as a terrorist organization (Reed, J. Todd and Raschke, Diana 2010: 103 - 104).

After the riots that occurred in July and September 2009, Al-Qaeda in the Islamic Maghreb (AQIM) called for attacking Chinese workers in North Africa. That was the first time that China was threatened by Al-Qaeda directly. On October 2009, another threat was issued from AQIM, when the Libyan regional group leader Abu Yahya Al-Libi 
posted a video on the internet condemning China for discrimination against Chinese Muslims. China's approach to anti-terrorism is different from the Western approach on two aspects. The first is China's focus on the strong link between separatism and terrorism, which influences its policies in Western China. The second is China's focus on multilateral cooperation instead of unilateral action with emphasis on sovereignty, equality of states, and consensus building (Lanteigne 2012: 95 - 102).

However, Yitzhak Shichor has clarified that China has not differentiated between the militant Uyghur organizations and between the moderate and political mainstream organizations. China started to realize the international dimension of Uyghur separatism in early 1990s. But only in the mid-1990s, it started to exercise pressure on host governments. However, the Chinese pressure was more effective on Central Asia and Turkey, but it failed on Western countries. Yitzhak Shichor also down played the influence of Islam compared to Uyghur nationalism in Uyghur inspirations. Before the late 1970s, the significance of Islam in Uyghur nationalism was limited, but after that the rise of political Islam in Iran; the Soviet Union invasion of Afghanistan; and the collapse of the Soviet Union had led to the emergence of Islam in Uyghur identity. However, the presence of radical Islam in Xinjiang is limited because of Beijing's central government control of religious affairs through the Xinjiang Islamic Religion Institute and China Islamic Association. The latter is an official state organization and determines the curriculum for the former. All clergymen in Xinjiang should be graduates of Xinjiang Islamic Religion Institute. The presence of radical Islam is also limited within overseas Uyghur organizations, because they know that their case will lose and they will embarrass their host countries, if they embrace radical Islam. Besides the Uyghur leaders 
in northern Xinjiang and overseas organizations are influenced by their secular education. However, radical Islamist groups or individuals most likely receive their teachings in neighboring countries like Pakistan or Afghanistan, but after the US invasion of Afghanistan and Chinese pressure on Pakistan this issue has become limited also (Shichor 2005: 122 - 129).

In spite of, the change in China's policy towards Xinjiang, the new policy is counterproductive to some extent. Domestically, China sought to develop Xinjiang to integrate it with China proper and achieve the satisfaction of minorities in Xinjiang through the Great Western Development policy. But this policy has led to contradicting results, because the benefits of development were unevenly received by the people in Xinjiang, as the Han, who were better educated, have better opportunities and standard of living compared to the minorities in Xinjiang. And even the Han later on started to consider the policies of Beijing like affirmative action as biased towards the minorities against them, which increased friction between the minorities and Han in Xinjiang. Another contradiction in Beijing policy of development was related to the integration of Xinjiang with China proper and Central Asia to act as center of integration and interaction between Europe, Central Asia, and East Asia. But the Open-up Policy had led to negative external influence like the rise of religious extremism and contacts with Uyghur organizations in Central Asian republics, which undermine China's control over Xinjiang. Regionally, China's Open-up Policy towards Central Asian republics to secure development and stability in Xinjiang was contradicting with the goals of China to some extent. The unrest in Xinjiang, on the $5^{\text {th }}$ of July 2009, was met by regional countries especially Kazakhstan and Kyrgyzstan very weakly. That position was due to the 
developed relations with China within SCO and the bilateral economic relations with China. On the other hand, the Uyghur populations in both countries were not happy with the weak response of their governments to the unrest in Xinjiang. Hence, while the governments' relations with China are strong, the people perceive China negatively. In the Islamic world especially in the Middle East, China has succeeded also in establishing strong relations with the governments of the region which resulted in disappearance of any strong position on any unrest in Xinjiang, and also the governments consider China to be a future balancer of the US in the Middle East, and accordingly are trying to keep strong relations with China. However, the public in the Islamic world has a stronger position than the governments, like Indonesia where different associations and institutions called for solidarity with the Uyghur. The only exception in the Islamic world had been Turkey and Iran. The former due to its cultural and ethnic affinity to the region, while the latter clerical establishment criticized suppression of Uyghur and called for the Organization of the Islamic Conference to intervene on behalf of the Uyghur, but the Iranian government has not taken a strong position on the issue to preserve the strong relations with China. Internationally, China's policy of claiming that Uyghur organizations in exile are terrorist and extremist groups responsible for unrest in Xinjiang, has lost its credibility as there is no connection between such groups and terrorist organizations. China's policy after 9/11 was also counterproductive when it insisted to depict the Uyghur organizations in exile as united and under one leadership, especially focusing on Rebiya Kadeer as the leader of such united organizations under the World Uyghur Congress (WUC), which raised the profile of Rebiya Kadeer and Uyghur issue. But in reality the Uyghur organizations used to be divided before that by 
geography and strategy (Clarke 2010: 215 - 225). In fact, earlier the Uyghur exiles lacked the organization and funding compared to Tibetan exiles, which decreased their effectiveness in acquiring support for their cause, besides the negative image of Islam in the West (Mackerras 2001: 294 -295), but the situation has changed especially after the establishment of WUC.

\section{The rise of Islamists in the Middle East and Uyghur in Xinjiang:}

In spite of, the causes of unrest and ethnic conflict in Xinjiang, it is not expected that the sovereignty of China in the province will be challenged under any circumstances. Whatever the role played by ethnic separatism or religious extremism in Xinjiang, the causes behind the unrest in the province can be carefully handled through wise policies that address especially the economic and social factors behind the tension. Beijing's policy change mentioned above is a sign about the careful and wise Chinese policies in this regard. Although the Reform and Open-up policy had its side negative effects on the province, as it was explained earlier, but the long run benefits are much more important than the negative aspects of the rise of Pan-Turkism and Pan-Islamism. Liza Steele and Raymond Kuo had proposed policy prescriptions for the settlement of the unrest in Xinjiang. "Beijing should reform local institutions to address Uighur concerns over discrimination; Beijing should support moderate Uighur leaders and engage in political dialogue with groups seeking greater autonomy (but who are not necessarily pushing for independence); and Beijing must create the necessary political space in China as a whole by delinking Uighur nationalism from issues of state legitimacy" (Steele and Kuo 2007: $15)$. 
It seems that the Arab league has not played a strong role in the case of Muslim minorities all over the world. However, that role has been played by the Organization of Islamic Cooperation (OIC), but still the role of the organization has always been peaceful and it can not be expected to negatively influence the sovereignty of China in Xinjiang. Most of the time, the organization seeks to cooperate with China to handle the concerns, that it raises about Muslims in Xinjiang.

The website of the OIC has declared that on the $28^{\text {th }}$ of June 2012, Prof Ekmeleddin Ihsanoglu, Secretary General of OIC, has discussed with Head of the Chinese People's Political Consultative Conference (CPPCC), Mr. Jia Qinglin, ways to expand relations between the OIC and China. Mr. Jia Qinglin referred to China's respect for the Muslims' freedom of worship and developmental programs implemented to enhance standard of living in Xinjiang. Prof Ihsanoglu confirmed the OIC's steady follow-up of the living conditions of Muslim minorities all over the world, and while cooperating with official channels of countries where those minorities are living, OIC adhere to its charter principles of non-interference in the internal affairs of those countries and the preservation of their sovereignty, national borders, and territorial integrity.

On the $27^{\text {th }}$ of June 2012, Prof Ihsanoglu has visited China and inaugurated an international conference in Beijing themed: "China and the Islamic World - Convergent Cultures". He quoted during the conference the Chinese prime minister, who has said in an earlier meeting in January 2012 that "the relationship between China and OIC is of strategic importance and will not be affected by any problems in the region". 
The website of OIC has declared that Prof Ihsanoglu has addressed also a message to the third session of the forum between China and West Asia and North Africa countries, on cooperation on small and medium enterprises (SMEs) in Tianjin, China. The OIC member states traded over US\$500 billion with China in 2011 which makes them the second largest partner with China after the EU.

Accordingly, the strong relations between OIC and China, and the principles of the OIC charter do not suggest that the future will witness any negative role played by the OIC towards China's sovereignty in Xinjiang.

On the other hand, the changes in the Middle East are profound. The rise of Islamists in the region, after the uprisings in some of the countries, has raised concerns about the future policies of the new regimes under the Islamists. The Muslim Brotherhood in Egypt does not have a declared policy towards Muslim minorities all over the world. Its presidential candidate in Egypt Dr Mohamed Morsy, who won the elections in June 2012, has not mentioned any thing in his presidential program about Muslim minorities, on the contrary his program talked about enhancing relationship with BRICS group as a rising power in the international system.

It is not expected that the new regimes in the region whether under the leadership of Islamists or other groups will embrace a policy that negatively influences China's sovereignty in Xinjiang, like recognizing the goals of separatist groups. First of all, the new regimes in the region will give priority to consolidating the internal situation, which may take few years due to the backward economic and social situation in the region, and 
Chinese investment and loans will be highly appreciated in this regard compared to Western conditionality on loans.

In addition, the new regimes, especially the Islamists, will be keen to establish strong relations with China as an alternative to the US if the relations with latter deteriorated for one reason or another. Besides, the case of Xinjiang will be very sensitive, because there are other cases which will be influenced if the policies of the new regimes in the region changed towards Xinjiang. The case of Chechnya is very close and Russia will be very sensitive if the Islamists in the region changed their policies towards the sovereignty of China over Xinjiang. Also the case of Kosovo is another example. Since the declaration of independence of Kosovo the main Arab countries have not recognized it. The Arab countries considered that recognizing Kosovo will create precedence that can be used later on against the Arab countries themselves due to the presence of many ethnic groups in the Middle East.

In general, the sovereignty of China over Xinjiang will not be affected, but China might expect some of the conservative religious groups, who used to be suppressed by the previous regimes in the Middle East, to raise the issue of Muslim minorities in general including the Chinese Uyghur in the media and in the new parliaments in the future, but even then China can handle such situations very carefully, especially if there is no corresponding change in the governments' official policies.

However, the main concern for China should be the possibility of spreading the uprising in the Middle East to Central Asia, where Muslim groups are also suppressed by secular regimes. The situation is close to the Middle East, and if Central Asia neighbors 
Mohamed Elhomosany, INTP 595, Page 71 of 84.

witnessed the same changes like the Middle East and the Islamists assumed power in Central Asia, then China has to worry about its sovereignty over Xinjiang. 


\section{Conclusion:}

The international system has witnessed a lot of changes since the early 1990s, like the collapse of the Soviet Union; the 9/11 attacks; and the rise of new major powers most prominent among them is China. The international system is gradually moving towards a multi-polar system. Member states within international institutions, like the UN, are debating about reform of such institutions to reflect the changes in the international system.

Reform and change is not only confined to the international system, but also different regions all over the world are looking for reform. Since the collapse of the Soviet Union several countries have witnessed a revolution or an uprising calling for reform on the political, economic, and social levels. The Middle East is not an exception in this regard. Beginning of late 2010 and early 2011, the Middle East has witnessed several uprisings against old regimes in the region.

The beginning was in Tunisia then Egypt, Libya, Yemen, Bahrain (cracked down very quickly), Syria, and Sudan, which is the most recent case, although it is not very aggressive like Syria. Three countries have witnessed free elections after the uprisings, which are Tunisia, Egypt, and Libya. The most prominent feature of the change in the region is the rise of Islamists. Although the Islamists degree of success was not the same in the elections in the three countries, but at least they managed to establish themselves as strong political groups in the three countries and throughout the region.

The nature of the future regimes in the Middle East is not very clear for the time being and it may take some time before this issue becomes clear, but certainly the change 
in the region will open opportunities for some countries and impose challenges for others. The opportunities and challenges will include regional countries and international powers. In fact, China will face both challenges and opportunities at the same time.

The research has sought to explore the influence of the rise of the Islamists on the Chinese interests in the region. Traditionally, China had three main interests in the Middle East. The first are the political and strategic interests. The second are the economic interests. The third is the linkage or influence of the situation in the Middle East on the situation in Xinjiang and China's sovereignty over the province.

After the Reform and Open-up Policy started in the late 1970s, China started to implement oil diplomacy in the region and the main goal for China was to implement a policy that enhances reform and growth at home. The political and strategic interests of China in the region were mainly driven by ideological aspects before the beginning of the reform in China in the late 1970s, but after that China started to build relations with the region on a pragmatic basis. The economic interests of China after the beginning of the reform were driven mainly by what is called Oil Diplomacy. China had built strong relations with the Gulf States and Iran to balance the US in the region gradually; as a hedge against the US in case of Iran, if the relations between the US and China deteriorated; to secure its energy needs; and to gain new markets and increase its exports.

As a late comer to the region, it was easier for China to build relations with the rogue states in the region, which oppose the US policy in the region, but China managed also to build relations with some of the allies of the US in the region. China was helpful for several regimes in the region through selling weapons to them that they can not get 
from the US and the West, especially missiles and weapons of mass destruction. China succeeded also in building good relations with Israel as a source of modern Western technology, which is important for China to upgrade its army.

The changes in the Middle East and the rise of Islamists opened opportunities for China through building relations with the new regimes in countries, like Egypt, which used to be considered pro-Western by China. However, the research has clarified some challenges that may face China especially in the short run, such challenges, which include the presence of interest groups and institutions domestically that may defend the interests of the West and the US; the presence of agreements that will put limits on the ability of the new regimes to get rid of the commitments of the previous regimes; the loyalty of the new regimes to the West and the US, who supported the rebels against the previous regimes while China adhered to the policy of non-interference which was considered by the rebels as a tacit support for the previous regimes.

Libya is a very clear example in this regard, it seems that China was able to overcome its previous political positions during the internal civil war in Libya and started to build new relations with the new regime, as it was clarified earlier. The other example is Egypt, where the strong relations between the military institution and the US represented by the annual military assistance, put restrictions on the freedom of the new regime to change the previous commitments of the old regime.

However, a change in the policies of the new regimes away from the West and towards China can occur, if the Islamists managed to fully control the new regimes and the ideological differences between them and the US started to appear, but this will take 
some time before it can happen, taking into consideration that the Islamists might also reach to an agreement securing the interests of the US in the region in exchange for recognition from the US and keep a kind of balance between the US and China.

In general, it will take some time before China can consider that the rise of Islamists in the Middle East will influence positively its political and strategic interests in the region and the research concludes that the rise of Islamists will not positively influence the political/strategic and economic interests of China in the Middle East at least in the short run.

The territorial integrity of China or its sovereignty over Xinjiang is the third main interest for China in the region. There is no serious threat for China's sovereignty over Xinjiang, taking into consideration the rising power of China and the policy changes implemented by Beijing. Although, the Chinese policy of development and integration of Xinjiang has its own positives and negatives, but in the long run the situation in Xinjiang will be more stable with increased standard of living in the province, especially if China handle the causes of continued unrest in the province.

The rise of the Islamists in the Middle East will not negatively influence the sovereignty of China over Xinjiang, due to several reasons. First, the strong relations between OIC and China, and the principles of the OIC charter of non-interference in the internal affairs of those countries, which host Muslim minorities, and the preservation of their sovereignty, national borders, and territorial integrity. Second, the new regimes in the region will give priority to consolidating the internal situation. Third, the new regimes, especially the Islamists, will be keen to establish strong relations with China as 
an alternative to the US if the relations with the latter deteriorated for one reason or another. Fourth, any change in the policies of the new regimes in the region towards Xinjiang or Muslim minorities will lead to sensitivity with other major powers like Russia, which has a large Muslim minority in Chechnya in the same region (Central Asia). Fifth, the Arab countries would fear the creation of any precedence that can be used against them later on, due to the presence of several minority groups in the Middle East.

China might expect the issues of Muslim minorities all over the world to be raised in the media in the Middle East more frequently than the previous era of the old regimes, but such situations can be handled carefully by China. The main concern for China should be the possibility of spreading the Arab Spring to Central Asia, where the situation in the region is similar to the Middle East with secular regimes repressing religious groups, if Islamists assume power in Central Asia then China should worry about its sovereignty over Xinjiang.

On the level of theory, the research highlights the importance of neo-realism in explaining most of the policies of China in the region and also other major powers, and as a framework of analysis. China does not feel secure about its energy needs. Hence, it started building its relationship with the Middle East to secure its energy needs. The anarchy and competition in the international system was very clear in this regard. The prospects of competition are higher than cooperation with limited energy resources all over the world. China's suspicions towards the West and the US had led to favoring balancing over bandwagoning. 
China prefers to secure its energy resources through direct equity shares or equity production in oil producing countries than depending on the international market that is dominated by the Western companies. Even the network of pipelines in Central Asia shows that China feels more secure by gradually decreasing its dependence on the Malacca Strait to avoid the possibility of blocking the sea lanes by the US in any conflict or the presence of terrorism and piracy in the Indian Ocean and Southeast Asia.

Finally, the developments in Syria suggest a great power competition in the Middle East especially after China used its veto power for the third time together with Russia to block the Western resolutions against Syria; backlashes the West for what happened in the case of Libya; and preserve its credibility with its allies in the region. The uprising in Syria could be the beginning of a new era, which will witness the rise of China and a new multi-polar system. 


\section{$\underline{\text { References: }}$}

Baker, Melinda Beth (2010) 'Beyond Oil?: Chinese National Interests and the SinoIranian Relationship', A Thesis submitted to the faculty of the Graduate School of Arts and Sciences of George Town University.

Blank, Stephen (2003) 'Xinjiang and China's security', Global Economic Review: Perspectives on East Asian Economies and Industries 32 (4): 121 - 148.

Buszynski, Leszek (December 2003) 'Asean, the Declaration on Conduct, and the South China Sea', Contemporary Southeast Asia: a Journal of International and Strategic Affairs 25(3): $343-362$.

Calabrese, John (Summer 1998) 'China and the Persian Gulf: Energy and Security', Middle East Journal 52(3): 351 - 366.

Chen, Qimao (March 1993) 'New Approaches in China's Foreign Policy: The Post-Cold War Era', Asian Survey 33(3): 237- 251.

Clarke, Michael (2010) 'China, Xinjiang and the internationalization of the Uyghur issue', Global Change, Peace \& Security: Formerly Pacifica Review: Peace, Security \& Global Change 22(2): 213 - 229.

Downs, Erica S. (March 2004) 'The Chinese Energy Security Debate', The China Quarterly (177): 21 - 41.

Friedman, George 'The State of the World: Assessing China's Strategy', Stratfor, 06/03/2012.

Gentry, J. Brandon (November 2005) 'The Dragon and the Magi: Burgeoning SinoIranian Relations in the 21st Century', The China and Eurasia Forum Quarterly 3(3): 111 -125 .

Hao, Yufan and Liu, Weihua (2012) 'Xinjiang: increasing pain in the heart of China's borderland', Journal of Contemporary China 21(74): 205 - 225. 
Jiang, Julie and Sinton, Jonathan 'Overseas Investments by Chinese National Oil Companies: Assessing the Drivers and Impacts', International Energy Agency (IEA), Information Paper, February 2011.

Kennedy, Andrew B. (2010) 'China's new energy-security debate', Survival 52(3): 137 158.

Lanteigne, Marc 'The same boat under wind and rain? China's anti-terrorism policies since 9/11', in 9/11 Ten years after: perspectives and problems (ed) Rachel E. Utley, Ashgate Publishing Limited, 2012, chapter 5, pp $89-105$.

Larson, Deborah Welch and Shevchenko, Alexei (Spring 2010) 'Status Seekers: Chinese and Russian Responses to U.S. Primacy', International Security 34(4): 63 - 95.

Liangxiang, Jin (Spring 2005) 'Energy First: China and the Middle East', Middle East Quarterly 12(2): 3-10.

Mackerras, Colin (2001) 'Xinjiang at the turn of the century: The causes of separatism', Central Asian Survey 20(3): 289 - 303.

Marshall, Shana 'Egypt's other Revolution: Modernizing the Military-Industrial Complex', Jadaliyya, 10/02/2012.

Marshall, Shana 'Why the U.S. won't cut military aid to Egypt?', Foreign Policy, 29/02/2012.

Marshall, Shana and Stacher, Joshua (spring 2012) 'Egypt's Generals and Transnational Capital', Middle East Report 42 (26).

Raghavan, Sudarsan and Higgins, Andrew 'China in a tug of war between two Sudans', The Washington Post, 24/3/2012.

Reed, J. Todd and Raschke, Diana, The ETIM: China's Islamic Militants and the Global Terrorist Threat, Praeger, 2010.

Rubin, Barry (March 1999) 'China's Middle East Strategy', Middle East Review of International Affairs 3(1): $46-54$. 
Russell, Richard L. (September 2005) 'China's WMD foot in the Greater Middle East's Door', Middle East Review of International Affairs 9(3): 108 - 124.

Shai, Aron (September 2009) 'Sino-Israeli Relations: Current Reality and Future Prospects', Institute for National Security Studies, Memorandum No. 100: 1 - 66.

Sharp, Jeremy M. 'U.S. Foreign Assistance to the Middle East: Historical Background, Recent Trends, and the FY2011 Request', Congressional Research Service (CRS) Report for Congress RL32260, 15/06/2010.

Shichor, Yitzhak (2005) 'Blow up: Internal and External challenges of Uyghur separatism and Islamic radicalism to Chinese rule in Xinjiang', Asian Affairs: An American Review (32)2: 119 - 136.

Shichor, Yitzhak (Fall 2000) 'Mountains out of molehills: Arms Transfers in Sino-Middle Eastern Relations', Middle East Review of International Affairs 4(3): 68 - 79.

Steele, Liza and Kuo, Raymond (2007) 'Terrorism in Xinjiang?', Ethnopolitics: Formerly Global Review of Ethnopolitics 6(1): 1 - 19.

Taylor, Ian (2006) 'China's Oil Diplomacy in Africa', International Affairs 82(5): 937 959.

Yao, Yuanming Alvin (September 2006) 'China's oil strategy and its implications for U.S.-China Relations', Issues \& Studies 42(3): 165 - 201.

Yergin, Daniel (2006) 'Ensuring Energy Security', Foreign Affairs 85(2): 69 - 82.

Yetiv, Steve A. and Lu, Chunlong (Spring 2007) 'China, Global Energy, and the Middle East', Middle East Journal 61(2): 199 - 218.

Zweig, David and Jianhai, Bi (2005) 'China's Global Hunt for Energy', Foreign Affairs 84(5): $25-38$. 


\section{Bibliography:}

Barnes, Joe and Jaffe, Amy Myers (2006) 'The Persian Gulf and the Geopolitics of Oil', Survival: Global Politics and Strategy 48(1): 143 - 162.

Braml, Josef (Autumn 2007) 'Can the United States Shed Its Oil Addiction?', The Washington Quarterly 30(4): 117 - 130.

Bull, Stanley R and Billman, Lynn (Winter 2000) 'Renewable Energy: Ready to Meet Its Promise?', The Washington Quarterly 23(1): 229 - 244.

Cao, Huhua and Maimaitiming, Anwaer 'Urban-rural Income Disparity and Urbanization: What is the Role of Spatial Distribution of Ethnic Groups? A Case Study of Xinjiang Uygur Autonomous Region in Western China'.

Carlson, Allen (Summer 2012) 'New Chinese Discussions about Securing China's Territorial Frontier', Orbis 56(3): 412 - 428.

Clarke, Michael (2007) 'China's Internal Security Dilemma and the Great Western Development: The Dynamics of Integration, Ethnic Nationalism and Terrorism in Xinjiang', Asian Studies Review 31(3): 323 - 342.

Clarke, Michael (October 2007) ' The Problematic Progress of Integration in the Chinese State's Approach to Xinjiang: 1759 - 2005', Asian Ethnicity 8(3): 261 - 289.

Cooley, Alexander (2008) 'Principles in the pipeline: managing transatlantic values and interests in Central Asia', International Affairs 84(6): 1173 - 1188.

Cordesman, Anthony H. 'Geopolitics and Energy in the Middle East', Center for Strategic and International Studies, September 1999.

Daojiong, Zha and Weixing, $\mathrm{Hu}$ (Autumn 2007) 'Promoting Energy Partnership in Beijing and Washington', The Washington Quarterly 30(4): 105 - 115.

Davis, Elizabeth Van Wie (2008) ' Uyghur Muslim Ethnic Separatism in Xinjiang, China', Asian Affairs: An American Review 35(1): 15 - 30. 
Engdahl, F. William, 'China lays down the Gauntlet in Energy War', available at: http://www.engdahl.oilgeopolitics.net/Geopolitics__Eurasia/China_Gauntlet/china_gaun tlet.html

Engdahl, F. William, 'China's Land Bridge to Turkey creates new Eurasian Geopolitical Potentials', 28 April 2012.

Gladney, Dru C. (November 1994) ' Sino-Middle Eastern Perspectives and Relations since the Gulf War: Views from below', International Journal of Middle East Studies 26(4): $677-691$.

Grose, Timothy A. (March 2010) 'The Xinjiang Class: Education, Integration, and the Uyghurs', Journal of Muslim Minority Affairs 30(1): 97 - 109.

Hall, Gregory and Grant, Tiara (2009) ' Russia, China, and the Energy-Security Politics of the Caspian Sea Region after the Cold War', Mediterranean Quarterly 20(2): 113 137.

Harris, Lillian Craig (March 1993) 'Xinjiang, Central Asia and the Implications for China's Policy in the Islamic World', The China Quarterly (133): 111 - 129.

Hu, Liyan and Cheng, Ter-Shing (November 2008) 'China's Energy Security and GeoEconomic Interests in Central Asia', Central European Journal of International and Security Studies 2(2): $42-55$.

Lai, Hongyi Harry (2007) 'China's Oil Diplomacy: is it a global security threat?', Third World Quarterly 28(3): 519 - 537.

Leverett, Flynt and Bader, Jeffrey (Winter 2005-06) 'Managing China-U.S. energy Competition in the Middle East', The Washington Quarterly 29(1): 187 - 201.

Mulligan, Shane (November 2010) 'Energy, Environment, and Security: Critical Links in a Post-Peak World', Global Environmental Politics 10(4): 79 - 100.

Pan, Guang (December 1997) 'China's Success in the Middle East', Middle East Quarterly 4(4): 35 - 40. 
Philippens, Henry 'Fueling China's Maritime Modernization: The Need to Guarantee Energy Security', December 2011.

Raczka, Witt (1998) 'Xinjiang and its Central Asian borderlands', Central Asian Survey 17(3): $373-407$.

Rousseau, Richard (2011) 'Competing Geopolitical Interests of China, Russia and the United States in Central Asia and the Caspian Region', Khazar Journal of Humanities and Social Sciences 14(3): 13 - 30.

Sager, Abdulaziz and Kemp, Geoffrey 'China's Growing Role in the Middle East: Implications for the Region and Beyond', Gulf Research Center (GRC) and Nixon Center, November 2009.

Shaffer, Brenda 'A Caspian Alternative to OPEC', The Wall Street Journal: A22, 2001.

Sharp, Jeremy M. 'Egypt in Transition', Congressional Research Service (CRS) Report for Congress 7-5700 RL33003, 23/08/2011.

Sharp, Jeremy M. 'Egypt: Background and U.S. Relations', Congressional Research Service (CRS) Report for Congress RL33003, 12/05/2009.

Verrastro, Frank and Ladislaw, Sarah (Autumn 2007) 'Providing Energy Security in an Interdependent World', The Washington Quarterly 30(4): 95 - 104.

Weinrod, W. Bruce (Spring 2006) 'US and European Approaches to China', Mediterranean Quarterly 17(2): 17 - 31.

Williams, Paul A. and Tekin, Ali (Summer, 2008) 'The Iraq War, Turkey, and Renewed Caspian Energy Prospects', Middle East Journal 62(3): 383 - 397.

Xinbo, Wu 'China and the United States: Core Interests, Common Interests, and Partnership', United States Institute of Peace, Special Report, June 2011.

Burchill, Scott and Linklater, Andrew (eds.), Theories of International Relations, Palgrave Macmillan, Fourth Edition, 2009. 
قوه، شوي تثشينغ "قراءة من بكين للموقف الصيني من الربيع العربي"، منتدى التعاون العربي الصيني، .2012/01/09

(Translation: Guo, Shui Qing 'Point of view from Beijing on the Chinese position towards the Arab Spring', China-Arab States Cooperation Forum, 09/01/2012).

جلال، محمد نعمان "الصين والتغيرات في العالم الإسلامي"، منتدى التعاون العربي الصيني، 2011/11/02.

(Translation: Galal, Mohamed Noaman 'China and the Changes in the Middle East', China-Arab States Cooperation Forum, 02/11/2011). 